\title{
The impact of anthropogenic emissions on atmospheric sulfate production pathways, oxidants, and ice core $\Delta^{17} \mathrm{O}\left(\mathrm{SO}_{4}^{2-}\right)$
}

\author{
E. D. Sofen ${ }^{1}$, B. Alexander ${ }^{1}$, and S. A. Kunasek ${ }^{2}$ \\ ${ }^{1}$ Department of Atmospheric Sciences, University of Washington, Box 351640, 408 ATG Building, Seattle, WA, 98195, USA \\ ${ }^{2}$ Department of Earth and Space Sciences, University of Washington, Johnson Hall Rm-070, Box 351310, Seattle, WA, \\ 98195, USA
}

Received: 31 July 2010 - Published in Atmos. Chem. Phys. Discuss.: 30 August 2010

Revised: 4 April 2011 - Accepted: 6 April 2011 - Published: 15 April 2011

\begin{abstract}
We use a global three-dimensional chemical transport model to quantify the influence of anthropogenic emissions on atmospheric sulfate production mechanisms and oxidant concentrations constrained by observations of the oxygen isotopic composition $\left(\Delta^{17} \mathrm{O}=\delta^{17} \mathrm{O}-0.52 \times \delta^{18} \mathrm{O}\right)$ of sulfate in Greenland and Antarctic ice cores and aerosols. The oxygen isotopic composition of non-sea salt sulfate $\left(\Delta^{17} \mathrm{O}\left(\mathrm{SO}_{4}^{2-}\right)\right)$ is a function of the relative importance of each oxidant (e.g. $\mathrm{O}_{3}, \mathrm{OH}, \mathrm{H}_{2} \mathrm{O}_{2}$, and $\mathrm{O}_{2}$ ) during sulfate formation, and can be used to quantify sulfate production pathways. Due to its dependence on oxidant concentrations, $\Delta^{17} \mathrm{O}\left(\mathrm{SO}_{4}^{2-}\right)$ has been suggested as a proxy for paleooxidant levels. However, the oxygen isotopic composition of sulfate from both Greenland and Antarctic ice cores shows a trend opposite to that expected from the known increase in the concentration of tropospheric $\mathrm{O}_{3}$ since the preindustrial period. The model simulates a significant increase in the fraction of sulfate formed via oxidation by $\mathrm{O}_{2}$ catalyzed by transition metals in the present-day Northern Hemisphere troposphere (from $11 \%$ to $22 \%$ ), offset by decreases in the fractions of sulfate formed by $\mathrm{O}_{3}$ and $\mathrm{H}_{2} \mathrm{O}_{2}$. There is little change, globally, in the fraction of tropospheric sulfate produced by gas-phase oxidation (from 23\% to 27\%). The model-calculated change in $\Delta^{17} \mathrm{O}\left(\mathrm{SO}_{4}^{2-}\right)$ since preindustrial times (1850 CE) is consistent with Arctic and Antarctic observations. The model simulates a $42 \%$ increase in the concentration of global mean tropospheric $\mathrm{O}_{3}$, a $10 \%$ decrease in $\mathrm{OH}$, and a $58 \%$ increase in $\mathrm{H}_{2} \mathrm{O}_{2}$ between the preindustrial period and present. Model results indicate that the observed decrease in the Arctic $\Delta^{17} \mathrm{O}\left(\mathrm{SO}_{4}^{2-}\right)$ - in spite of increasing tropospheric $\mathrm{O}_{3}$ concentrations - can be explained by the combined effects of increased sulfate forma-
\end{abstract}

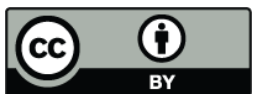

Correspondence to: B. Alexander (beckya@atmos.washington.edu) tion by $\mathrm{O}_{2}$ catalyzed by anthropogenic transition metals and increased cloud water acidity, rendering $\Delta^{17} \mathrm{O}\left(\mathrm{SO}_{4}^{2-}\right)$ insensitive to changing oxidant concentrations in the Arctic on this timescale. In Antarctica, the $\Delta^{17} \mathrm{O}\left(\mathrm{SO}_{4}^{2-}\right)$ is sensitive to relative changes of oxidant concentrations because cloud $\mathrm{pH}$ and metal emissions have not varied significantly in the Southern Hemisphere on this timescale, although the response of $\Delta^{17} \mathrm{O}\left(\mathrm{SO}_{4}^{2-}\right)$ to the modeled changes in oxidants is small. There is little net change in the $\Delta^{17} \mathrm{O}\left(\mathrm{SO}_{4}^{2-}\right)$ in Antarctica, in spite of increased $\mathrm{O}_{3}$, which can be explained by a compensatory effect from an even larger increase in $\mathrm{H}_{2} \mathrm{O}_{2}$. In the model, decreased oxidation by $\mathrm{OH}$ (due to lower $\mathrm{OH}$ concentrations) and $\mathrm{O}_{3}$ (due to higher $\mathrm{H}_{2} \mathrm{O}_{2}$ concentrations) results in little net change in $\Delta^{17} \mathrm{O}\left(\mathrm{SO}_{4}^{2-}\right)$ due to offsetting effects of $\Delta^{17} \mathrm{O}(\mathrm{OH})$ and $\Delta^{17} \mathrm{O}\left(\mathrm{O}_{3}\right)$. Additional model simulations are conducted to explore the sensitivity of the oxygen isotopic composition of sulfate to uncertainties in the preindustrial emissions of oxidant precursors.

\section{Introduction}

Atmospheric sulfate $\left(\mathrm{SO}_{4}^{2-}\right)$ aerosols impact numerous aspects of the Earth system and have been significantly altered by human activity. Sulfate aerosols have a direct radiative cooling effect and contribute to indirect radiative effects through modification of cloud properties. However, the extent of the cooling effect remains highly uncertain (Solomon et al., 2007). Sulfate is also a major source of acidity in aerosols and cloud water, impacting $\mathrm{pH}$-dependent atmospheric chemistry and the $\mathrm{pH}$ of precipitation. Sulfur emissions, mainly in the form of sulfur dioxide gas $\left(\mathrm{SO}_{2}\right)$, have increased dramatically due to anthropogenic activity (Langner et al., 1992; Smith et al., 2011). 
Sulfur enters the atmosphere mainly through natural emissions of dimethyl sulfide (DMS) produced by marine phytoplankton and through natural and anthropogenic emissions of $\mathrm{SO}_{2}$, mainly as a combustion byproduct. Most atmospheric sulfate, which is a major component of atmospheric aerosols, is produced through oxidation of $\mathrm{SO}_{2}$ in the atmosphere. The extent to which $\mathrm{SO}_{2}$ emissions impact the sulfate aerosol radiative effects depends in part on whether sulfate is formed through gas- or aqueous-phase chemistry. Gas-phase oxidation of $\mathrm{SO}_{2}$ results the formation of new particles that, under favorable conditions, can go on to form cloud condensation nuclei. Aqueous-phase sulfate formation will not form new particles, but can affect aerosol and cloud droplet growth (Kaufman and Tanre, 1994).

Oxygen triple-isotope $\left({ }^{16} \mathrm{O},{ }^{17} \mathrm{O},{ }^{18} \mathrm{O}\right)$ measurements of sulfate have been used previously to infer the atmospheric formation pathways of sulfate in the present (Lee et al., 2001; Lee and Thiemens, 2001; Alexander et al., 2005, 2009; Patris et al., 2007; Dominguez et al., 2008) and paleo(Alexander et al., 2002, 2003, 2004; Kunasek et al., 2010) atmosphere. Most chemical and physical processes fractionate isotopes in a mass-dependent manner. However, a few processes - most importantly, the formation of $\mathrm{O}_{3}-$ have been found to fractionate oxygen isotopes in a nonmass-dependent fashion (Thiemens and Heidenreich, 1983). This mass-independent fractionation is used as a tracer of a number of atmospheric processes, largely related to oxidant chemistry (Brenninkmeijer et al., 2003; Thiemens, 2006), as well as the hydrologic cycle (Barkan and Luz, 2007; Landais et al., 2008) and biological productivity (Luz et al., 1999; Landais et al., 2007). The oxygen isotopic composition of sulfate reflects the relative importance of different oxidants $\left(\mathrm{O}_{3}, \mathrm{H}_{2} \mathrm{O}_{2}, \mathrm{OH}\right.$, and $\left.\mathrm{O}_{2}\right)$ in the production of sulfate because the oxidants transfer unique oxygen isotope signatures to the oxidation product (Savarino et al., 2000). In addition, due to the partial dependence of the isotopic composition of sulfate on oxidant concentrations, ice core observations of the oxygen isotopes of sulfate have been suggested as a potential proxy for paleo-oxidant concentrations.

The concentrations of the tropospheric oxidants, including ozone $\left(\mathrm{O}_{3}\right)$, hydroxyl radical $(\mathrm{OH})$, and hydrogen peroxide $\left(\mathrm{H}_{2} \mathrm{O}_{2}\right)$, are described collectively as the "oxidizing capacity of the atmosphere" (Thompson, 1992). Variations in the oxidizing capacity of the troposphere impact the lifetimes of chemically and radiatively important reduced trace gases, such as carbon monoxide $(\mathrm{CO})$, methane $\left(\mathrm{CH}_{4}\right)$, and halocarbons. However, the extent to which the oxidizing capacity of the troposphere has changed between the preindustrial Holocene (PI; prior to $1850 \mathrm{CE}$ ) and present-day (PD) due to anthropogenic activity remains highly uncertain.

Measurements of the $\mathrm{H}_{2} \mathrm{O}_{2}$ concentration (Sigg and Neftel, 1991) and $\mathrm{CH}_{2} \mathrm{O} / \mathrm{CH}_{4}$ ratio (Staffelbach et al., 1991) in ice cores have been studied as potential proxies of the past oxidizing capacity of the atmosphere. However, both $\mathrm{H}_{2} \mathrm{O}_{2}$ and $\mathrm{CH}_{2} \mathrm{O}$ are sensitive to post-depositional process- ing, hindering quantitative interpretation of past atmospheric conditions. There are also modern reconstructions of $\mathrm{O}_{3}$ measurements made in the late-nineteenth century using the Schönbein (Marenco et al., 1994; Pavelin et al., 1999) and oxidation of arsenate (Volz and Kley, 1988) methods. Errors in the reconstructed $\mathrm{O}_{3}$ measurements may arise from interferences by other oxidizing or reducing gases (Volz and Kley, 1988), humidity, uncertainties in the recalibration of the Schönbein method, and local $\mathrm{O}_{3}$ sources (Marenco et al., 1994). These reconstructions suggest very low surface $\mathrm{O}_{3}$ concentrations, on the order of $5-15 \mathrm{nmol} \mathrm{mol}^{-1}$.

Models are often used to simulate the changing oxidizing capacity of the atmosphere. However, between model studies, the fractional change in global mean oxidant concentrations between the PI and PD (PD-PI) varies greatly (e.g. Wang and Jacob, 1998; Thompson et al., 1993; Grenfell et al., 2001; Lamarque et al., 2005). Models predict PD-PI changes of +30 to $+65 \%$ in mean $\mathrm{O}_{3},-33 \%$ to $+10 \%$ in $\mathrm{OH}$, and $+40 \%$ to $+140 \%$ in $\mathrm{H}_{2} \mathrm{O}_{2}$. Inter-model variability in oxidants is due to differing meteorological fields, differing choices of $\mathrm{PI} \mathrm{CH}_{4}$ concentrations, uncertainties in PI biogenic and biomass-burning emissions, and inherent variations in PD models related to $\mathrm{NO}_{\mathrm{x}}$ and volatile organic compound (VOC) emissions and stratosphere-troposphere exchange of $\mathrm{O}_{3}$ (Wu et al., 2007). In addition to intermodel variability, Mickley et al. (2001) point out that most PI simulations overestimate surface $\mathrm{O}_{3}$ relative to the late1800s measurements described above. Mickley et al. (2001) achieved agreement with these measurements by dramatically lowering emissions of soil and lightning $\mathrm{NO}_{\mathrm{x}}$ and increasing emissions of biogenic VOCs. Due to the widely varying model approaches and the nonlinearity of oxidant chemistry, a proxy is needed for model validation of PI oxidant concentrations.

In this study, we use the three oxygen isotopes of atmospheric sulfate extracted from Greenland (Alexander et al., 2004) and Antarctic (Kunasek et al., 2010) ice cores as a constraint on anthropogenic emissions-based changes in sulfate formation pathways in the GEOS-Chem global chemical transport model and explore its use as a proxy for changes in paleo-oxidant concentrations between the PI and PD. In Sect. 2, we present an overview of sulfate formation and oxygen isotopes. Section 3 provides a description of the modeling approach, model limitations, and sensitivity studies. In Sect. 4, we discuss changes in the global sulfur budget induced by anthropogenic emissions and compare the model results to the ice core measurements. We also use the model to examine the sensitivity of the oxygen isotopes of sulfate to changing oxidant concentrations, emissions, and cloud $\mathrm{pH}$ on the PD-PI timescale. 


\section{Oxygen isotopic composition of sulfate}

Sulfate forms in the atmosphere through the oxidation of $\mathrm{SO}_{2}$ via gas-phase, aqueous-phase, and heterogeneous reaction pathways. The main sulfate-formation pathways are gasphase oxidation of $\mathrm{SO}_{2}$ by $\mathrm{OH}$ and aqueous-phase oxidation of S(IV) by $\mathrm{H}_{2} \mathrm{O}_{2}$ and $\mathrm{O}_{3}$ (Chin and Jacob, 1996), where $\mathrm{S}(\mathrm{IV})$ describes the total of the aqueous species formed by $\mathrm{SO}_{2}$ dissolution $\left(\mathrm{S}(\mathrm{IV})=\mathrm{SO}_{2} \cdot \mathrm{H}_{2} \mathrm{O}+\mathrm{HSO}_{3}^{-}+\mathrm{SO}_{3}^{2-}\right.$ ). In polluted high-latitude regions during winter, aqueousphase sulfate formation by molecular oxygen $\left(\mathrm{O}_{2}\right)$ catalyzed by transition metals (mainly $\mathrm{Fe}$ and $\mathrm{Mn}$ ) is also a significant pathway (Alexander et al., 2009; Munger et al., 1983; McCabe et al., 2006). Also, $\mathrm{SO}_{4}^{2-}$ forms through heterogeneous-phase oxidation by $\mathrm{O}_{3}$ on alkaline sea salt (Chameides and Stelson, 1992) and dust (Usher et al., 2003) aerosols. Aqueous-phase oxidation of S(IV) by halogens $(\mathrm{HOBr}$ and $\mathrm{HOCl}$ ) has been suggested to be important in the marine boundary layer (Vogt et al., 1996; von Glasow et al., 2002). However, this suggestion is based on the assumption that the rate constants for the reactions $\mathrm{HSO}_{3}^{-}+\mathrm{HOBr} / \mathrm{HOCl}$ are equal to the rate constants for $\mathrm{SO}_{3}^{2-}+\mathrm{HOBr} / \mathrm{HOCl}$, because only the latter has been measured (Fogelman et al., 1989; Troy and Margerum, 1991). This assumption represents a large source of uncertainty because $\mathrm{HSO}_{3}^{-}$is the dominant aqueous $\mathrm{S}(\mathrm{IV})$ species under typical cloud water $\mathrm{pH}(2-7)$ conditions. $\mathrm{NO}_{2}$ (Lee and Schwartz, 1983), $\mathrm{NO}_{3}$ (Feingold et al., 2002), and $\mathrm{HNO}_{4}$ (Dentener et al., 2002; Warneck, 1999) can also oxidize S(IV) in the aqueous phase. Because of the low solubility of $\mathrm{NO}_{2}, \mathrm{~S}(\mathrm{IV})+\mathrm{NO}_{2}$ is expected to be most important in polluted regions where $\mathrm{NO}_{2}$ concentrations are high. $\mathrm{NO}_{3}$ and $\mathrm{HNO}_{4}$ have been hypothesized to be important in high Northern latitude polluted regions during the winter, but oxygen isotope measurements of Arctic sulfate argue against this (McCabe et al., 2006). In this study, we consider sulfate formation by $\mathrm{OH}$ in the gas phase, $\mathrm{H}_{2} \mathrm{O}_{2}, \mathrm{O}_{3}$, and $\mathrm{O}_{2}$ catalyzed by $\mathrm{Fe}$ and $\mathrm{Mn}$ in the aqueous phase, and heterogeneous oxidation on fine- and coarse-mode sea salt aerosols by $\mathrm{O}_{3}$.

Measurements of the three isotopes of the oxygen $\left({ }^{16} \mathrm{O}\right.$, ${ }^{17} \mathrm{O},{ }^{18} \mathrm{O}$ ) in sulfate provide insight into the oxidation pathway by which sulfate formed, due to the anomalous massindependent isotopic signature that is passed to $\mathrm{SO}_{4}^{2-}$ by $\mathrm{O}_{3}$ and $\mathrm{H}_{2} \mathrm{O}_{2}$ (Savarino et al., 2000) during the oxidation of $\mathrm{S}(\mathrm{IV})$.

This mass-independent signature is described using the linear approximation as follows:

$\Delta^{17} \mathrm{O}=\delta^{17} \mathrm{O}-0.52 \times \delta^{18} \mathrm{O}$,

where

$\delta^{\mathrm{n}} \mathrm{O}=\left[\frac{\left(\left[{ }^{\mathrm{n}} \mathrm{O}\right] /\left[{ }^{16} \mathrm{O}\right]\right)_{\text {sample }}}{\left(\left[{ }^{\mathrm{n}} \mathrm{O}\right] /\left[{ }^{16} \mathrm{O}\right]\right)_{\text {standard }}}-1\right]$ for $n=\{17,18\}$.
Both $\delta$ and $\Delta$ are expressed as a parts-per-thousand deviation from a standard (Vienna Standard Mean Ocean Water) in units of "per mil" (\%o).

Field, laboratory, and modeling studies find that in the troposphere $\Delta{ }^{17} \mathrm{O}\left(\mathrm{O}_{3}\right)=6-54 \%$ (Johnston and Thiemens, 1997; Krankowsky et al., 1995; Lyons, 2001), $\Delta^{17} \mathrm{O}\left(\mathrm{H}_{2} \mathrm{O}_{2}\right)=0.9-2.2 \%$ (Savarino and Thiemens, 1999; Lyons, 2001$), \Delta{ }^{17} \mathrm{O}(\mathrm{OH}) \approx 0 \%$, and $\Delta^{17} \mathrm{O}\left(\mathrm{O}_{2}\right)=-0.34 \%$ o (Barkan and Luz, 2005). The widely varying $\Delta^{17} \mathrm{O}\left(\mathrm{O}_{3}\right)$ measurements have a mean value of $25 \%$. The large spread of observed $\Delta^{17} \mathrm{O}\left(\mathrm{O}_{3}\right)$ is unexpected based on the temperature- and pressure-dependence of $\Delta^{17} \mathrm{O}\left(\mathrm{O}_{3}\right)$ during ozone formation in laboratory studies (Morton et al., 1990). Due to potential sampling artifacts from measurements of atmospheric $\Delta^{17} \mathrm{O}\left(\mathrm{O}_{3}\right)$ (Brenninkmeijer et al., 2003), we assume $\Delta{ }^{17} \mathrm{O}\left(\mathrm{O}_{3}\right)=35 \%$ o based on calculations by (Lyons, 2001), following Michalski et al. (2003). For $\mathrm{H}_{2} \mathrm{O}_{2}$, we use $\Delta{ }^{17} \mathrm{O}\left(\mathrm{H}_{2} \mathrm{O}_{2}\right)=1.3 \%$, the mean of the measurements by Savarino and Thiemens (1999). For $\mathrm{OH}$ and $\mathrm{O}_{2}$, we assume $\Delta^{17} \mathrm{O}(\mathrm{OH})=0 \%$ and $\Delta{ }^{17} \mathrm{O}\left(\mathrm{O}_{2}\right)=-0.34 \%$. Sensitivity studies are performed to investigate the influence of these assumptions on our results (Sect. 4.5).

The $\Delta^{17} \mathrm{O}$ of atmospheric sulfate $\left(\Delta^{17} \mathrm{O}\left(\mathrm{SO}_{4}^{2-}\right)\right)$ depends on the $\Delta^{17} \mathrm{O}$ transferred to sulfate by each oxidant during S(IV) oxidation (Savarino et al., 2000) and the fraction of sulfate formed through each oxidation pathway. The assumptions described above lead to $\Delta^{17} \mathrm{O}\left(\mathrm{SO}_{4}^{2-}\right)=8.75 \%$ o $\left(\mathrm{O}_{3}\right)$, $0.65 \% 0\left(\mathrm{H}_{2} \mathrm{O}_{2}\right), 0 \% 0(\mathrm{OH})$, and $-0.09 \% 0\left(\mathrm{O}_{2}\right)$ for each oxidation pathway. The fraction of sulfate formed through each oxidation pathway depends on oxidant concentrations, cloud liquid water content, cloud-water $\mathrm{pH}$, atmospheric metal concentrations, and aerosol surface area.

\section{Model description}

We use version 8-01-01 of the GEOS-Chem global, threedimensional atmospheric chemical transport model (Bey et al., 2001, http://www.geos-chem.org) at $4^{\circ} \times 5^{\circ}$ resolution to simulate oxidant concentrations, atmospheric sulfur chemistry, and the resulting $\Delta^{17} \mathrm{O}\left(\mathrm{SO}_{4}^{2-}\right)$ of the PI and PD atmosphere. The model is driven by present-day assimilated Goddard Earth Observing System (GEOS-4) meteorology. Base-case PI and PD simulations are run for ten years (1988-1997). Sensitivity studies are conducted with 1989-1991 meteorology. The PD simulation relies on the standard GEOS-Chem emissions inventories - GEIA fossil fuel, fertilizer, biogenic, and biofuel emissions (Wang et al., 1998) supplemented by EMEP (Vestreng and Klein, 2002), BRAVO (Kuhns et al., 2003), EDGAR (Olivier et al., 2005), and Streets et al. (2006) regional inventories, MEGAN 2.0 biogenic emissions (Millet et al., 2008), and GFED2 biomass burning emissions from the year 1997 (Giglio and Werf, 2006). Anthropogenic emissions are scaled by national energy and $\mathrm{CO}_{2}$ emission data for 1988-1997. $\mathrm{PD} \mathrm{CH}_{4}$ 
concentrations for four latitude bands $\left(90^{\circ} \mathrm{N}-30^{\circ} \mathrm{N}, 30^{\circ} \mathrm{N}-\right.$ $0^{\circ}, 0^{\circ}-30^{\circ} \mathrm{S}, 30^{\circ} \mathrm{S}-90^{\circ} \mathrm{S}$ ) are based on interpolated annual flask measurement data (Dlugokencky et al., 2008). For PI simulations, we turn off fossil fuel and fertilizer emissions, scale biomass burning emissions to $10 \%$ of PD levels (following Crutzen and Zimmermann, 1991, and others); biofuel, lightning, and biogenic emissions remain at their PD levels. We set PI $\mathrm{CH}_{4}$ to the $1850 \mathrm{CE}$ global mean concentration of $792 \mathrm{nmol} \mathrm{mol}^{-1}$ (Etheridge et al., 2002).

Global monthly-mean oxidant fields $\left(\mathrm{O}_{3}, \mathrm{OH}\right.$, and $\mathrm{NO}_{3}$ concentrations, $\mathrm{H}_{2} \mathrm{O}_{2}$ production and photolysis rates) and total inorganic nitrate are archived from $\mathrm{NO}_{\mathrm{x}}-\mathrm{O}_{\mathrm{x}}-$ hydrocarbon-aerosol "full-chemistry" simulations (two-year spin-up, ten-year simulation; three-year simulation for sensitivity studies) and used in "offline" tagged-sulfate aerosol simulations as described in Park et al. (2004) and Alexander et al. (2009). The tagged sulfate formation pathways are gasphase oxidation by $\mathrm{OH}$, aqueous-phase oxidation by $\mathrm{H}_{2} \mathrm{O}_{2}$, $\mathrm{O}_{3}$, and $\mathrm{O}_{2}$ catalyzed by $\mathrm{Fe}$ and $\mathrm{Mn}$, and heterogeneous oxidation by $\mathrm{O}_{3}$ on coarse- and fine-mode sea salt aerosols. Other sulfate formation pathways are not included for reasons discussed in Sect. 2.

The calculated annual average PD-PI change in $\Delta^{17} \mathrm{O}\left(\mathrm{SO}_{4}^{2-}\right)$ is compared to measurements from $\mathrm{PD}$ aerosol samples in Alert, Canada (McCabe et al., 2006) and ice cores from (PI) Site-A, Greenland (Alexander et al., 2004) and (PD and PI) WAIS-Divide, Antarctica (Kunasek et al., 2010). We also compare our model results to the measurements of late-1800s $\mathrm{O}_{3}$ and ice core $\mathrm{H}_{2} \mathrm{O}_{2}$.

\subsection{Comparison of the model with PD observations}

Figure 1a compares the PD modeled $\Delta^{17} \mathrm{O}\left(\mathrm{SO}_{4}^{2-}\right)$ to all available annual and monthly measurements of $\Delta^{17} \mathrm{O}\left(\mathrm{SO}_{4}^{2-}\right)$ from aerosol, precipitation, and firn samples. The model and most measurements represent non-sea salt sulfate. Measurements at South Pole (Michalski, personal communication, 2001; McCabe, personal communication, 2004) represent total sulfate, as $\mathrm{Na}^{+}$data are not available to correct for sea salt sulfate, which will bias these $\Delta^{17} \mathrm{O}\left(\mathrm{SO}_{4}^{2-}\right)$ observations low. Therefore, wintertime (JJA) measurements of South Pole $\Delta^{17} \mathrm{O}\left(\mathrm{SO}_{4}^{2-}\right)$ are excluded from Fig. 1a, as sea salt sulfate can represent $10-60 \%$ of total sulfate during the winter (Harder et al., 2000). Sea salt contributes approximately $1 \%$ of total sulfate during summer (December) (Harder et al., 2000), which will impact the $\Delta^{17} \mathrm{O}\left(\mathrm{SO}_{4}^{2-}\right)$ by approximately $0.01 \%$ - much less than the uncertainty in the measurements. Bulk cloud water $\mathrm{pH}$ values of 4.5 and 5.0 are assumed for the Northern and Southern Hemispheres, respectively, consistent with the increased acidity of Northern Hemisphere precipitation by anthropogenic emissions of nitric and sulfuric acid precursors. The model $(0.2-2.1 \%$ o captures the range of variability in the observations $(0.4-2.4 \%$ ) . Scatter in the model-measurement comparison $\left(R^{2}=0.40\right)$
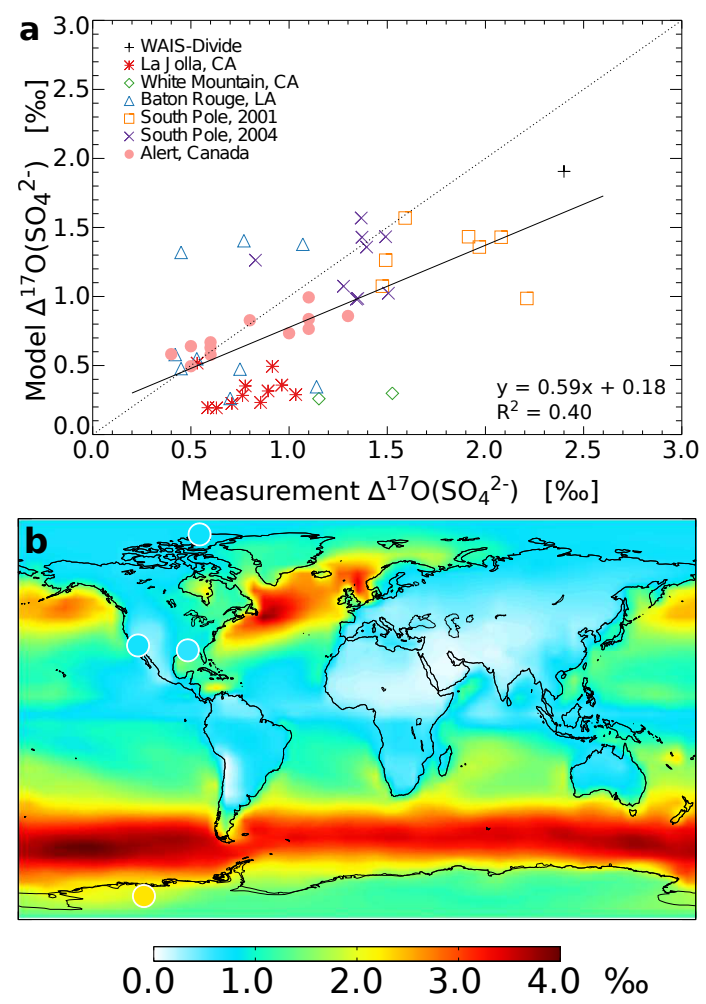

Fig. 1. Comparison of modeled $\mathrm{PD} \Delta^{17} \mathrm{O}\left(\mathrm{SO}_{4}^{2-}\right)$ at the surface to observations. The scatter plot (a) compares annual (WAIS-Divide, Antarctica Kunasek et al., 2010) and monthly (La Jolla, CA, White Mountain Research Station, CA (Lee, 2000), Baton Rouge, LA (Jenkins and Bao, 2006), South Pole, Antarctica (G. Michalski, personal communication, 2001; J. McCabe, personal communication, 2004), Alert Canada McCabe et al., 2006) $\Delta^{17} \mathrm{O}\left(\mathrm{SO}_{4}^{2-}\right)$ observations from firn, aerosols, and precipitation to model results for the same time periods. The linear least-squares regression line (solid) and $y=x$ line (dotted) are shown. Where annual data is available (Alert, La Jolla, Baton Rouge, and WAIS-Divide), it is overplotted on a map (b) of the modeled annual-mean surface $\Delta^{17} \mathrm{O}\left(\mathrm{SO}_{4}^{2-}\right)$.

(Fig. 1a) is likely due at least in part to variations in cloud $\mathrm{pH}$ not calculated in the model.

Figure $1 \mathrm{~b}$ compares modeled annual mean surface $\Delta^{17} \mathrm{O}\left(\mathrm{SO}_{4}^{2-}\right)$ with observations at locations with enough data to calculate annual mean values. The model captures the spatial variability in $\Delta^{17} \mathrm{O}\left(\mathrm{SO}_{4}^{2-}\right)$ observations (e.g. latitudinal gradient). Furthermore, the model captures the seasonal cycle in $\Delta^{17} \mathrm{O}\left(\mathrm{SO}_{4}^{2-}\right)$ at Alert, Canada (Alexander et al., 2009) and is within the uncertainty of the two sets of monthly-mean measurements from South Pole. The model underestimates $\Delta^{17} \mathrm{O}\left(\mathrm{SO}_{4}^{2-}\right)$ at La Jolla, California (by $0.4 \%$ on average) and exaggerates the seasonal cycle at Baton Rouge, Louisiana. Both La Jolla and Baton Rouge are coastal sites, where the model does not have the resolution to resolve the strong chemical gradients across the coastlines. 


\subsection{Model limitations}

Calculations of sulfate production, assessment of the relation between oxidants and $\Delta^{17} \mathrm{O}\left(\mathrm{SO}_{4}^{2-}\right)$, and interpretation of ice core $\Delta^{17} \mathrm{O}\left(\mathrm{SO}_{4}^{2-}\right)$ observations on the PI-PD timescale are made uncertain by limitations in our modeling framework. Factors that contribute to this uncertainty include assumptions related to meteorology fields, emissions, sulfur chemistry, oxidant chemistry, the $\Delta{ }^{17} \mathrm{O}$ of oxidants $\left(\mathrm{OH}, \mathrm{O}_{3}\right.$, $\mathrm{H}_{2} \mathrm{O}_{2}$ ), and the transfer of $\Delta^{17} \mathrm{O}$ from the oxidants to sulfate.

We assume that on the PD-PI timescale, changes in climate have a small effect on sulfur and oxidant chemistry compared to the emissions changes described in Sect. 1 . Meteorological fields impact both oxidant and sulfur chemistry. Changes in the water vapor content of the atmosphere impact $\mathrm{OH}$ concentrations. Changes in the strength of stratosphere-troposphere exchange can impact both the concentration and isotopic composition of tropospheric $\mathrm{O}_{3}$, because stratospheric $\mathrm{O}_{3}$ has a $5-10 \%$ o higher $\Delta^{17} \mathrm{O}$ than tropospheric ozone (Mauersberger, 1987; Krankowsky et al., 2000). Cloud liquid water content, which impacts the relative fractions of $\mathrm{SO}_{4}^{2-}$ formed in the gas- and aqueous-phase, is calculated in the model based on cloud fraction and temperature and is therefore held constant between PI and PD simulations. There is little evidence that global cloud liquid water content has changed on the PD-PI timescale. General circulation models do suggest that global cloud liquid water has slightly increased on this timescale, but this is highly uncertain (Lohmann and Feichter, 2005; Wang et al., 2011). Finally, windspeed influences the emission of alkaline sea salt aerosols, and thus the importance of heterogeneous sulfate formation. By assuming no change in meteorology, any change in the modeled $\Delta^{17} \mathrm{O}\left(\mathrm{SO}_{4}^{2-}\right)$ is due to a change in oxidant concentrations, cloud $\mathrm{pH}$, or metal emissions.

Emissions from biomass burning include both oxidant precursors and sinks, so biomass burning can strongly influence oxidant concentrations. Preindustrial biomass burning emissions are highly uncertain. As is done here, model studies typically assume that PI biomass burning was greatly reduced $(10 \%)$ compared to to PD biomass burning and that the geographic distribution is unchanged. However, a recent study of the isotopic composition of $\mathrm{CO}$ from an Antarctic ice core suggests that there was more Southern Hemisphere biomass burning in the PI (1700-1850 CE) than the PD (1991 CE) (Wang et al., 2010).

The strength of emissions of metals ( $\mathrm{Mn}$ and $\mathrm{Fe}$ ) to the atmosphere, along with their solubility and oxidation state, are highly uncertain, and influence the relative importance of the $\mathrm{S}(\mathrm{IV})+\mathrm{O}_{2}$ pathway. Alexander et al. (2009) suggested that metal-catalyzed sulfate formation is dominated by anthropogenic metals in mid- to high-latitudes during winter and is necessary to explain the observed seasonal cycle of $\Delta^{17} \mathrm{O}\left(\mathrm{SO}_{4}^{2-}\right)$ in Arctic aerosol (McCabe et al., 2006). Modeled metal emissions are scaled to mineral dust and primary anthropogenic sulfate, following Alexander et al. (2009). Thus, only metal in dust is included in the PI.

The choice of global cloud water $\mathrm{pH}$ contributes to uncertainty in $\Delta^{17} \mathrm{O}\left(\mathrm{SO}_{4}^{2-}\right)$, since $\mathrm{S}(\mathrm{IV})+\mathrm{O}_{3}$ is highly $\mathrm{pH}$ dependent. Cloud water $\mathrm{pH}$ on the PD-PI timescale is impacted by anthropogenic emissions of sulfuric and nitric acid precursors in the Northern Hemisphere. In the Northern high latitudes the acidity of precipitation has increased since the PI (Mayewski et al., 1986), while there has been no change in the Antarctic. Cragin et al. (1987) showed that a South Pole ice core spanning the past 2000 years has an average $\mathrm{pH}$ of $5.37 \pm 0.08$ with no trend in time. We expect the chemically relevant cloud water $\mathrm{pH}$ to be somewhat lower than the $\mathrm{pH}$ of precipitation reported by Cragin et al. (1987), as precipitation is likely made up of larger, more dilute droplets than bulk cloud water. This is further supported by the correlation between $\mathrm{pH}$ and droplet size (Straub et al., 2007) and seasonally averaged measurements of both cloud droplet and precipitation $\mathrm{pH}$, which show an offset of $0.7 \pm 0.1$ between the precipitation and cloud $\mathrm{pH}$ at Whiteface Mountain, NY (Aleksic et al., 2009).

There are several sulfate formation pathways that are not included in the model, such as S(IV) oxidation by $\mathrm{HOCl}, \mathrm{HOBr}, \mathrm{NO}_{2}, \mathrm{NO}_{3}$, and $\mathrm{HNO}_{4}$. We do not include these sulfate formation pathways in our model calculations because either their rate constants are unknown $\left(\mathrm{HOCl} / \mathrm{HOBr}+\mathrm{HSO}_{3}^{-}\right)$or the pathways are thought to be minor contributors to total sulfate formation $\left(\mathrm{NO}_{2}, \mathrm{NO}_{3}\right.$, and $\mathrm{HNO}_{4}$ ), as discussed in more detail in Sect. 2.

Modeled PD tropospheric column ozone in GEOS-Chem compares well to multiple sets of observations (Chandra et al., 2003; Liu et al., 2006). Recent work suggests other reactions, not included in the GEOS-Chem chemical mechanism used here, may impact oxidant concentrations on the PD-PI timescale. Results from Archibald et al. (2011) suggest that $\mathrm{HO}_{\mathrm{x}}$ recycling in the photo-oxidation of isoprene impacts oxidant concentrations. In particular, their PI simulation that includes $\mathrm{HO}_{\mathrm{x}}$ recycling increases the tropospheric burden of both $\mathrm{OH}$ and $\mathrm{O}_{3}$ by $49 \%$ and $18 \%$, respectively, relative to their base PI simulation. However, $\mathrm{HO}_{\mathrm{x}}$ recycling mechanisms in forested regions are highly uncertain. Recent results by Stone et al. (2011) demonstrate that none of the current suggestions for $\mathrm{HO}_{\mathrm{x}}$ recycling mechanisms can reproduce observed concentrations of both $\mathrm{OH}$ and $\mathrm{HO}_{2}$ over a forest. In addition, results from Parrella et al. (2010) suggest that including reactive bromine chemistry in GEOSChem lowers PI surface $\mathrm{O}_{3}$ by $24 \%$ in agreement with the late-1800 $\mathrm{S}_{3}$ measurements. However, the introduction of bromine chemistry does produce some discrepancies with $\mathrm{PD} \mathrm{O}_{3}$ measurements.

Tropospheric $\mathrm{O}_{3}$ measurements span a range of $\Delta{ }^{17} \mathrm{O}\left(\mathrm{O}_{3}\right)$, and we assume a value near the upper end of the range $(35 \%)$ due to potential sampling artifacts (Brenninkmeijer et al., 2003) that likely bias the observations low. In polar regions, stratospheric $\mathrm{O}_{3}$ intrusions 
may increase $\Delta^{17} \mathrm{O}\left(\mathrm{O}_{3}\right)$. Although the model captures stratosphere-troposphere exchange of $\mathrm{O}_{3}$, we do not consider its effect on tropospheric $\Delta^{17} \mathrm{O}\left(\mathrm{O}_{3}\right)$. Also, Morin et al. (2007) postulated that the non-zero $\Delta^{17} \mathrm{O}$ of $\mathrm{OH}$ formed from $\mathrm{O}_{3}$ may not be eliminated by isotopic exchange with water vapor in polar regions because of the low water vapor content. Finally, Savarino et al. (2008) have demonstrated that in the case of $\mathrm{NO}+\mathrm{O}_{3}$, the terminal $\mathrm{O}$ atoms in $\mathrm{O}_{3}$ are preferentially transferred compared to the central $\mathrm{O}$ atom. This results in a higher $\Delta^{17} \mathrm{O}\left(\mathrm{NO}_{2}\right)$ than would be predicted based on the bulk $\Delta^{17} \mathrm{O}\left(\mathrm{O}_{3}\right)$ because of the isotopic asymmetry of $\mathrm{O}_{3}$ (Janssen, 2005; Bhattacharya et al., 2008; Michalski and Bhattacharya, 2009). If $\mathrm{S}(\mathrm{IV})+\mathrm{O}_{3}$ occurs through a similar mechanism, this could lead to a higher $\Delta^{17} \mathrm{O}\left(\mathrm{SO}_{4}^{2-}\right)$ in sulfate formed by $\mathrm{O}_{3}$. To mitigate errors in our $\Delta^{17} \mathrm{O}$ assumptions we focus on the PD-PI change in $\Delta^{17} \mathrm{O}\left(\mathrm{SO}_{4}^{2-}\right)$, rather than its absolute value. Errors in our assumptions regarding oxidant $\Delta^{17} \mathrm{O}$ values may offset modeled $\Delta^{17} \mathrm{O}\left(\mathrm{SO}_{4}^{2-}\right)$ from its true value, but the influence will be similar in both time periods, so the PD-PI difference in $\Delta^{17} \mathrm{O}\left(\mathrm{SO}_{4}^{2-}\right)$ is largely unaffected. Focusing on the PD-PI change in $\Delta^{17} \mathrm{O}\left(\mathrm{SO}_{4}^{2-}\right)$ also mitigates errors associated with our assumptions regarding cloud $\mathrm{pH}$, as discussed in detail in Sect. 4.3.

\subsection{Sensitivity studies}

We conduct six sensitivity studies to explore the impact of model uncertainties on our conclusions. To assess the uncertainty in PI conditions, we conduct four additional simulations, varying (1) biomass burning emissions, (2) biogenic VOC and $\mathrm{NO}_{\mathrm{x}}$ emissions, (3) anthropogenic metal emissions, and (4) cloud water $\mathrm{pH}$. We also (5) assess the impact of individual oxidant changes on $\Delta^{17} \mathrm{O}\left(\mathrm{SO}_{4}^{2-}\right)$ and (6) the uncertainty in the $\Delta^{17} \mathrm{O}$ of oxidants.

Two sensitivity studies explore uncertainties in PI emissions of oxidant precursors and their impact on $\Delta^{17} \mathrm{O}\left(\mathrm{SO}_{4}^{2-}\right)$. The first uses PD biomass burning in a simulation with an otherwise-PI configuration. The second sensitivity study is modeled on the work of Mickley et al. (2001). We halve lightning and biomass-burning $\mathrm{NO}_{\mathrm{x}}$ emissions and double biogenic VOC emissions from their PI values to test whether modeled preindustrial oxidants can be consistent with both late-1800s $\mathrm{O}_{3}$ measurements and ice core $\Delta^{17} \mathrm{O}\left(\mathrm{SO}_{4}^{2-}\right)$.

To assess the sensitivity of $\Delta^{17} \mathrm{O}\left(\mathrm{SO}_{4}^{2-}\right)$ to anthropogenic metal ( $\mathrm{Mn}$ and $\mathrm{Fe}$ ) emissions, simulations are run both with and without metal-catalyzed oxidation.

Because of the uncertainty in assuming a fixed cloud water $\mathrm{pH}$, simulations are run at a bulk cloud water $\mathrm{pH}=4.5,5.0$, and 5.5. The best-fit $\mathrm{pH}$ values from the base simulations are used for all further sensitivity studies, and we focus on the difference in $\Delta^{17} \mathrm{O}\left(\mathrm{SO}_{4}^{2-}\right)$ between PI and PD simulations, which mitigates the uncertainty associated with assuming a fixed $\mathrm{pH}$, as described in Sects. 4.3 and 4.5.

To assess the sensitivity of $\Delta^{17} \mathrm{O}\left(\mathrm{SO}_{4}^{2-}\right)$ to changes in individual oxidant concentrations, $\mathrm{PD}$ simulations are run by substituting a single PI oxidant $\left(\mathrm{O}_{3}, \mathrm{OH}, \mathrm{H}_{2} \mathrm{O}_{2}\right)$.

Finally, to assess the sensitivity of the modeled PD-PI change in $\Delta^{17} \mathrm{O}\left(\mathrm{SO}_{4}^{2-}\right)$ to our oxidant $\Delta^{17} \mathrm{O}$ assumptions, the PD-PI difference in $\Delta^{17} \mathrm{O}\left(\mathrm{SO}_{4}^{2-}\right)$ is calculated based on oxidant $\Delta{ }^{17} \mathrm{O}$ values of $25 \%$ o for $\mathrm{O}_{3}$ and $3 \%$ o for $\mathrm{OH}$ following Morin et al. (2007).

\section{Results and discussion}

\subsection{Sulfur budget}

Table 1 shows the global annual tropospheric sulfur budget in the PI and PD simulations assuming a cloud water $\mathrm{pH}$ of 5.0 in the PI and the PD Southern Hemisphere and a pH of 4.5 in the PD Northern Hemisphere. Sulfur emissions in the PD model are almost a factor of four higher than those in the PI model. The sulfate production rate increases by a factor of 3.3. The increase in the sulfate production rate is smaller than the increase in sulfur emissions because a larger fraction of $\mathrm{SO}_{2}$ is lost via dry deposition in the PD. The burdens of $\mathrm{SO}_{2}$ and $\mathrm{SO}_{4}^{2-}$ both increase by almost a factor of three. There is little change in the relative importance of sulfate formed in the gas phase (23\% to $27 \%$ ). The contribution of sulfate formed in the gas phase is important because only sulfate formed through gas-phase oxidation can nucleate new particles, increasing aerosol number density under favorable conditions. Metal-catalyzed oxidation increases in importance from $11 \%$ to $22 \%$ in the Northern Hemisphere, leading to a slight suppression in the relative importance of sulfate formation by $\mathrm{H}_{2} \mathrm{O}_{2}$ and $\mathrm{O}_{3}$.

\subsection{Global oxidants}

Figure 2a-c shows the PD-PI change in annual mean tropospheric oxidant concentrations. Global annual mean (10year average) tropospheric $\mathrm{O}_{3}$ increases by $42 \% \pm 1 \%$ (from $31.7 \pm 0.5$ to $\left.45.2 \pm 0.5 \mathrm{nmol} \mathrm{mol}^{-1}\right)$, OH decreases by $-9.9 \% \pm 0.5 \%$ (from $(1.37 \pm 0.04) \times 10^{6}$ to $(1.24 \pm 0.03) \times$ $10^{6} \mathrm{~cm}^{-3}$ ), and $\mathrm{H}_{2} \mathrm{O}_{2}$ increases by $58 \% \pm 2 \%$ (from $0.58 \pm$ 0.02 to $0.92 \pm 0.02 \mathrm{nmol} \mathrm{mol}^{-1}$ ), with one standard deviation uncertainties indicating the ten-year interannual variability in the modeled annual mean changes in oxidant concentrations. Our base-case simulations represent reasonably mainstream changes in $\mathrm{O}_{3}$ and $\mathrm{OH}$ compared to previous modeling studies (e.g. Thompson et al., 1993; Wang and Jacob, 1998; Grenfell et al., 2001; Lamarque et al., 2005).

While very few studies report PD-PI $\mathrm{H}_{2} \mathrm{O}_{2}$ changes, the $58 \%$ global increase in this study is within the range of other models (e.g. Thompson et al., 1993; Grenfell et al., 2001), and is in qualitative agreement with ice core measurements 

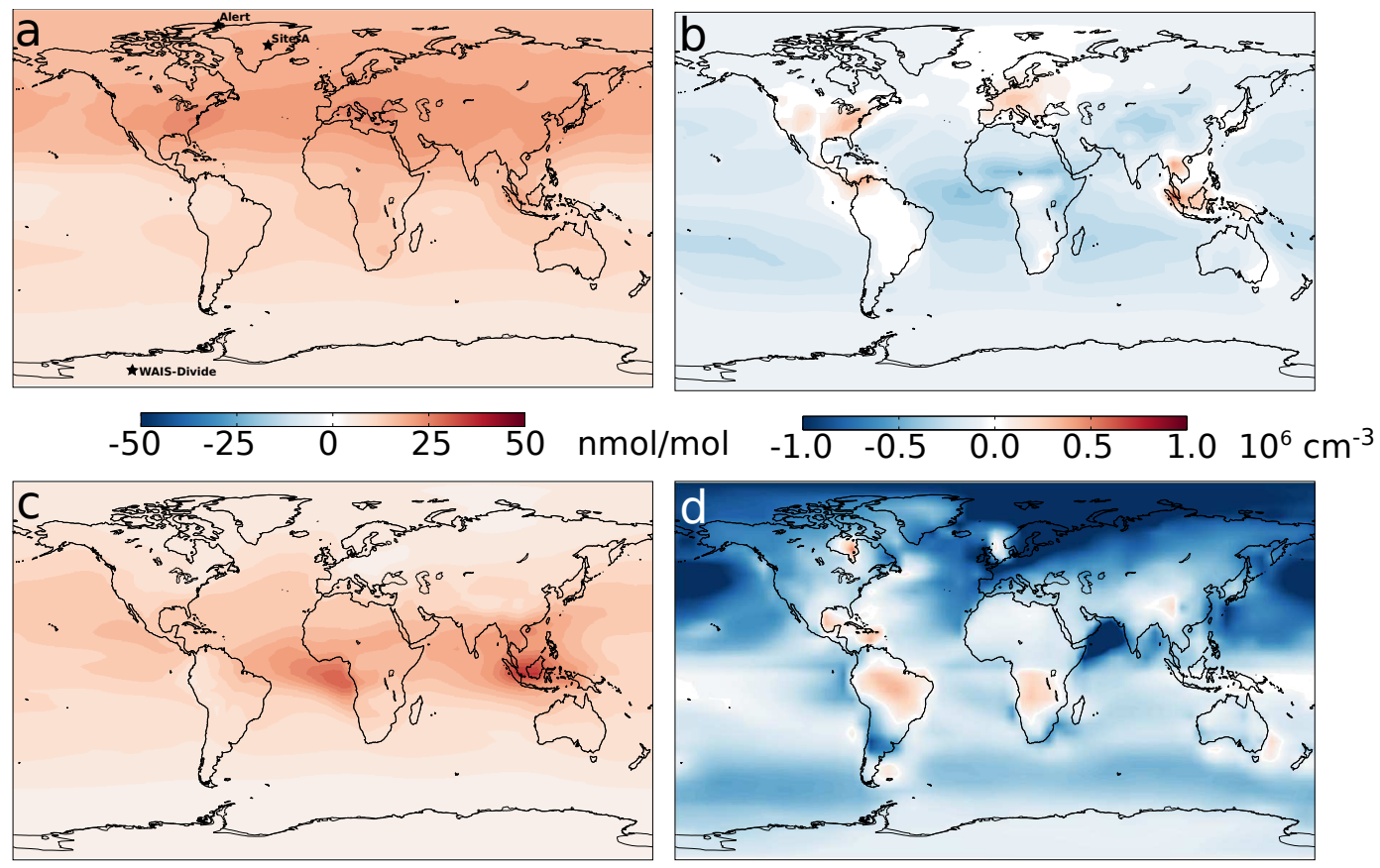

$-1.50-0.75 \quad 0.00 \quad 0.75 \quad 1.50 \mathrm{nmol} / \mathrm{mol}$

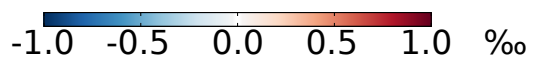

Fig. 2. PD-PI change in global tropospheric mean concentrations of (a) $\mathrm{O}_{3}$, (b) $\mathrm{OH}$, and (c) $\mathrm{H}_{2} \mathrm{O}_{2}$ and (d) the surface $\Delta^{17} \mathrm{O}\left(\mathrm{SO}_{4}^{2-}\right)$. The $\Delta^{17} \mathrm{O}\left(\mathrm{SO}_{4}^{2-}\right)$ plot $(\mathbf{d})$ is the difference of the $\mathrm{PI}(\mathrm{pH}=5.0)$ and $\mathrm{PD}(\mathrm{NH} \mathrm{pH}=4.5 ; \mathrm{SH} \mathrm{pH}=5.0)$ simulations. The measurement locations are shown in (a).

(Sigg and Neftel, 1991; Frey et al., 2006; Lamarque et al., 2011). A recent modeling study suggests that the increase in $\mathrm{H}_{2} \mathrm{O}_{2}$ in the latter 20th century is due to the decline in the Antarctic overhead $\mathrm{O}_{3}$ column, which leads to greater production of $\mathrm{H}_{2} \mathrm{O}_{2}$ initiated from $\mathrm{O}_{3}$ photolysis, while the earlier part of the increase can be explained by changes in tropospheric oxidant chemistry driven by emissions (Lamarque et al., 2011). Since the PI simulations presented here use PD stratospheric $\mathrm{O}_{3}$, the Antarctic $\mathrm{PI}_{2} \mathrm{O}_{2}$ concentrations may be overestimated and PD-PI change in $\mathrm{H}_{2} \mathrm{O}_{2}$ may be underestimated. However, the importance of the effect of the $\mathrm{O}_{3}$ column abundance on $\mathrm{H}_{2} \mathrm{O}_{2}$ will decrease with latitude (equatorward). Therefore, the effect of the overhead $\mathrm{O}_{3}$ column on $\mathrm{H}_{2} \mathrm{O}_{2}$ concentrations over the Southern Ocean (relevant to the formation of sulfate that is deposited to Antarctica) is likely much smaller than the effect on $\mathrm{H}_{2} \mathrm{O}_{2}$ over the Antarctic continent itself.

\subsection{Oxygen isotopes of sulfate}

Figure $2 \mathrm{~d}$ illustrates the corresponding PD-PI change in the annual mean $\Delta^{17} \mathrm{O}\left(\mathrm{SO}_{4}^{2-}\right)$ of deposited sulfate across the globe using the same $\mathrm{pH}$ assumptions as for Table 1. The interannual variability in the modeled $\Delta^{17} \mathrm{O}\left(\mathrm{SO}_{4}^{2-}\right)$ at the polar measurement locations is $\pm 0.2 \%$ o $(1 \sigma)$. The largest PDPI $\Delta^{17} \mathrm{O}\left(\mathrm{SO}_{4}^{2-}\right)$ decrease occurs in the Eurasian Arctic due to increased metal-catalyzed $\mathrm{SO}_{4}^{2-}$ formation and decreased cloud $\mathrm{pH}$. The largest $\Delta^{17} \mathrm{O}\left(\mathrm{SO}_{4}^{2-}\right)$ increase occurs in the Amazon region due to a decrease in the fraction of sulfate formed in the gas-phase.

Table 2 compares the PD-PI change in modeled $\Delta^{17} \mathrm{O}\left(\mathrm{SO}_{4}^{2-}\right)$ using various cloud $\mathrm{pH}$ assumptions to both Arctic (Site-A and Alert) and Antarctic (WAIS-Divide) measurements. For simulations at cloud water $\mathrm{pH}$ values of $4.5,5.0$, and 5.5, we consider both the absolute value of $\Delta^{17} \mathrm{O}\left(\mathrm{SO}_{4}^{2-}\right)$ and the PD-PI change in $\Delta^{17} \mathrm{O}\left(\mathrm{SO}_{4}^{2-}\right)$ at the ice core sites.

At WAIS-Divide, the modeled PD-PI change in $\Delta^{17} \mathrm{O}\left(\mathrm{SO}_{4}^{2-}\right)$ agrees with observations no matter what $\mathrm{pH}$ we assume $(4.5,5.0,5.5)$. However, the simulations at $\mathrm{pH}=5.0$ best matches the absolute magnitude of the $\Delta^{17} \mathrm{O}\left(\mathrm{SO}_{4}^{2-}\right)$ measurements. The $\mathrm{pH}=5.5$ simulations overestimates the $\Delta^{17} \mathrm{O}\left(\mathrm{SO}_{4}^{2-}\right)$ by more than $2.5 \%$, and the $\mathrm{pH}=4.5$ simulations underestimates $\Delta^{17} \mathrm{O}\left(\mathrm{SO}_{4}^{2-}\right)$ by $1 \%$. Because a $\mathrm{pH}$ of 5.0 provides better agreement with WAIS-Divide ice core measurements (D. Pasteris, personal communication, 2010) and is consistent with expectations of Antarctic cloud water $\mathrm{pH}$ (described in Sect. 3.2), we assume a $\mathrm{pH}$ of 5.0 in the Southern Hemisphere for all further simulations described below. 
Table 1. Global annual (ten-year) average sulfur budgets for PD and PI. Uncertainties represent one standard deviation of the ten one-year annual budgets. Parentheses indicate the fraction of sulfate production, $\mathrm{SO}_{2}$ deposition, and sulfate deposition associated with a particular pathway.

\begin{tabular}{|c|c|c|c|c|c|c|}
\hline & PD & & & PI & & \\
\hline Emissions ( $\mathrm{Tg} \mathrm{S} \mathrm{yr}^{-1}$ ) & 92.1 & \pm 0.2 & & 23.7 & \pm 0.2 & \\
\hline Anthropogenic $\mathrm{SO}_{2}$ & 65.0 & \pm 0.2 & & 0.0 & & \\
\hline Biomass Burning $\mathrm{SO}_{2}$ & 1.6 & & & 0.2 & & \\
\hline Biofuel $\mathrm{SO}_{2}$ & 0.3 & & & 0.3 & & \\
\hline Volcanic $\mathrm{SO}_{2}$ & 5.5 & & & 5.5 & & \\
\hline Anthropogenic $\mathrm{SO}_{4}^{2-}$ & 2.0 & & & 0.0 & & \\
\hline Ocean DMS & 17.8 & \pm 0.2 & & 17.8 & \pm 0.2 & \\
\hline $\mathrm{SO}_{2}$ from DMS $\left(\mathrm{Tg} \mathrm{S} \mathrm{yr}^{-1}\right)$ & 16.2 & \pm 0.2 & & 15.8 & \pm 0.2 & \\
\hline Sulfate Production ( $\operatorname{Tg~S~yr}^{-1}$ ) & 39.4 & \pm 0.4 & & 11.8 & \pm 0.2 & \\
\hline $\mathrm{SO}_{2}+\mathrm{OH}$ & 11.0 & \pm 0.2 & $(27 \%)$ & 2.85 & \pm 0.05 & $(23 \%)$ \\
\hline $\mathrm{S}(\mathrm{IV})+\mathrm{H}_{2} \mathrm{O}_{2}$ & 19.4 & \pm 0.4 & $(50 \%)$ & 7.1 & \pm 0.2 & $(62 \%)$ \\
\hline $\mathrm{S}(\mathrm{IV})+\mathrm{O}_{3}$ & 1.50 & \pm 0.05 & $(4 \%)$ & 0.76 & \pm 0.02 & $(6 \%)$ \\
\hline $\mathrm{S}(\mathrm{IV})+\mathrm{O}_{2}$ & 7.0 & \pm 0.4 & $(18 \%)$ & 0.88 & \pm 0.05 & $(8 \%)$ \\
\hline $\mathrm{S}(\mathrm{IV})+\mathrm{O}_{3}$ (sea salt) & 0.49 & \pm 0.01 & $(1 \%)$ & 0.25 & $6 \pm 0.007$ & $(2 \%)$ \\
\hline \multicolumn{7}{|l|}{ Burden (Tg S) } \\
\hline $\mathrm{SO}_{2}$ & 0.30 & $4 \pm 0.004$ & & 0.10 & $7 \pm 0.002$ & \\
\hline Sulfate & 0.56 & \pm 0.1 & & 0.19 & $0 \pm 0.006$ & \\
\hline 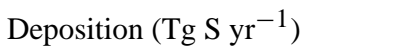 & 90.3 & \pm 0.3 & & 21.8 & \pm 0.1 & \\
\hline $\mathrm{SO}_{2}$ Dry Deposition & 32.6 & \pm 0.5 & $(68 \%)$ & 4.60 & \pm 0.05 & $(52 \%)$ \\
\hline $\mathrm{SO}_{2}$ Wet Deposition & 15.4 & \pm 0.3 & $(32 \%)$ & 4.2 & \pm 0.1 & $(48 \%)$ \\
\hline Sulfate Dry Deposition & 6.0 & \pm 0.2 & $(14 \%)$ & 1.33 & \pm 0.02 & $(11 \%)$ \\
\hline Sulfate Wet Deposition & 35.5 & \pm 0.6 & $(86 \%)$ & 10.6 & \pm 0.1 & $(89 \%)$ \\
\hline \multicolumn{7}{|l|}{ Lifetime (days) } \\
\hline $\mathrm{SO}_{2}$ & 1.27 & \pm 0.02 & & 1.89 & \pm 0.04 & \\
\hline Sulfate & 4.92 & \pm 0.8 & & 5.8 & \pm 0.1 & \\
\hline
\end{tabular}

In the Arctic, the modeled $\Delta^{17} \mathrm{O}\left(\mathrm{SO}_{4}^{2-}\right)$ is most consistent with PD aerosol and ice core measurements (Fig. 1) when the PD model is run at a $\mathrm{pH}$ of 4.5. The PI model is run at a cloud $\mathrm{pH}$ of 5.0, in line with the Southern Hemisphere. A PD Northern Hemisphere cloud pH of 5.0 or 5.5 is inconsistent with both the observed PD-PI decrease in the $\Delta^{17} \mathrm{O}\left(\mathrm{SO}_{4}^{2-}\right)$ at Summit, Greenland (Table 2) and other PD observations (Fig. 1). The above trend in $\mathrm{pH}$ is also consistent with $\mathrm{SO}_{4}^{2-}$ and $\mathrm{NO}_{3}^{-}$trends in Greenland ice cores (Mayewski et al., 1986). Based on these sensitivity studies, all other simulations assume a cloud $\mathrm{pH}$ of 5.0 except for the PD Northern Hemisphere where the $\mathrm{pH}$ is 4.5 .

\subsection{Sensitivity of $\Delta^{17} \mathrm{O}\left(\mathrm{SO}_{4}^{2-}\right)$ to regional oxidants}

The sensitivity of $\Delta^{17} \mathrm{O}\left(\mathrm{SO}_{4}^{2-}\right)$ to changing oxidants is best assessed using fractional changes in regional oxidants because $\Delta^{17} \mathrm{O}\left(\mathrm{SO}_{4}^{2-}\right)$ depends on the fraction of $\mathrm{SO}_{4}^{2-}$ formed by each pathway. Sulfate deposited at Alert, Canada is likely emitted from Eurasia and the Arctic, whereas sulfate at SiteA, Greenland is influenced by North America and the northern midlatitudes, as it is better exposed to the free troposphere due to its high elevation (Hirdman et al., 2010). A zonally-averaged profile of sulfate production rates indicates that most sulfate is produced below approximately $8.3 \mathrm{~km}$ altitude $(340 \mathrm{hPa})$ in the model. Therefore, we consider the fractional change in oxidants from the surface to $8.3 \mathrm{~km}$ altitude over the entire northern midlatitudes $\left(30^{\circ}-60^{\circ} \mathrm{N}\right)$. In this region, we find modeled PD-PI changes of $+53 \% \pm 3 \%$, $-10.3 \% \pm 0.7 \%$, and $+65 \% \pm 3 \%$, respectively, for $\mathrm{O}_{3} \mathrm{OH}$, and $\mathrm{H}_{2} \mathrm{O}_{2}$. There is little variation in these values compared with several similar sub-regions (North America, Greenland, $>60^{\circ} \mathrm{N}$ ) of the Northern Hemisphere. At Site-A, Greenland, we take the PI period to be prior to $1837 \mathrm{CE}$, as $\Delta^{17} \mathrm{O}\left(\mathrm{SO}_{4}^{2-}\right)$ increases in the Site-A record in the late-1800s due to increased North American biomass burning (Alexander et al., 2004), a condition not considered in these simulations. In spite of the $53 \%$ increase in $\mathrm{O}_{3}$ due to anthropogenic activity, there is a PD-PI decrease of $0.5 \%$ in the measured $\Delta^{17} \mathrm{O}\left(\mathrm{SO}_{4}^{2-}\right)$. The model reproduces this decrease in the $\Delta^{17} \mathrm{O}\left(\mathrm{SO}_{4}^{2-}\right)$ (Table 2). Table 3 illustrates how changes in the relative importance of each oxidant have impacted each sulfate formation pathway at the measurement locations. Coincident with increased $\mathrm{PD} \mathrm{O}_{3}$ production from anthropogenic precursors, increased anthropogenic metal emissions, primarily from coal-fired power plants, 
Table 2. Difference in $\Delta^{17} \mathrm{O}\left(\mathrm{SO}_{4}^{2-}\right)$ between PD and PI simulations (PD-PI). Sensitivity studies assume a cloud-water $\mathrm{pH}$ of 5.0 and are compared to the PI simulation run at a $\mathrm{pH}$ of 5.0. Bolditalics indicate agreement with measurements within the analytical uncertainty of the measurements. From the ten-year simulations, the $1 \sigma$ interannual variability in the modeled PD-PI change in $\Delta^{17} \mathrm{O}\left(\mathrm{SO}_{4}^{2-}\right)$ is $\pm 0.2 \%$ o for Site-A/Alert and $\pm 0.03 \%$ o for WAISDivide. "Met. Cat." indicates whether (Y) or not $(\mathrm{N})$ simulations include the metal-catalyzed S(IV) oxidation pathway. Measurements of the PD-PI difference in $\Delta^{17} \mathrm{O}\left(\mathrm{SO}_{4}^{2-}\right)$ from the Arctic (Site-A, Greenland and Alert, Canada) and the Antarctic (WAIS-Divide) are also shown.

\begin{tabular}{|c|c|c|c|c|}
\hline \multicolumn{3}{|c|}{ Simulation $\mathrm{pH}$} & \multicolumn{2}{|c|}{$\begin{array}{c}\text { PD-PI } \Delta^{17} \mathrm{O}\left(\mathrm{SO}_{4}^{2-}\right) \\
\text { Difference }\end{array}$} \\
\hline PD & PI & Met. Cat. & Arctic & Antarctic \\
\hline 4.5 & 4.5 & Y & 0.2 & 0.0 \\
\hline 4.5 & 5.0 & $\mathrm{Y}$ & -0.6 & -1.3 \\
\hline 4.5 & 5.5 & $\mathrm{Y}$ & -2.8 & -3.5 \\
\hline 5.0 & 5.0 & $\mathrm{Y}$ & 0.2 & -0.2 \\
\hline 5.0 & 5.5 & $\mathrm{Y}$ & -2.0 & -2.7 \\
\hline 5.5 & 5.5 & $\mathrm{Y}$ & -0.3 & -0.3 \\
\hline 4.5 & 5.0 & $\mathrm{~N}$ & 0.0 & -1.3 \\
\hline 5.0 & 5.0 & $\mathrm{~N}$ & 2.3 & -0.5 \\
\hline \multicolumn{5}{|c|}{ Sens. Studies $-\mathrm{S}-\mathrm{PI}(\mathrm{pH}=5.0$, Met. Cat.=Y) } \\
\hline \multirow{2}{*}{\multicolumn{3}{|c|}{$\begin{array}{l}\text { PD Biomass Burning } \\
\text { low- } \mathrm{NO}_{\mathrm{x}} / \text { high-VOC }\end{array}$}} & 0.0 & 0.0 \\
\hline & & & -0.2 & -0.5 \\
\hline \multicolumn{3}{|c|}{ Measurements } & $-0.5 \pm 0.3$ & $-0.2 \pm 0.2$ \\
\hline
\end{tabular}

increase the fraction of Site-A sulfate formed by $\mathrm{S}(\mathrm{IV})+\mathrm{O}_{2}$ $\left(\Delta^{17} \mathrm{O}\left(\mathrm{O}_{2}\right)=-0.34 \%\right.$ ) from $8 \%$ (PI) to $21 \%$ (PD). During winter in the PD Northern Hemisphere, when oxidant concentrations are low due to reduced photochemistry and $\mathrm{SO}_{2}$ concentrations are high due to anthropogenic emissions, $\mathrm{H}_{2} \mathrm{O}_{2}$ is titrated by $\mathrm{SO}_{2}$. This, along with low wintertime $\mathrm{OH}$ concentrations and low cloud $\mathrm{pH}(<5)$, allows metalcatalyzed $\mathrm{S}(\mathrm{IV})+\mathrm{O}_{2}$ to dominate $\mathrm{SO}_{4}^{2-}$ production. Once this $\mathrm{H}_{2} \mathrm{O}_{2}$ titration "threshold" is met, the relative importance of metal-catalyzed sulfate formation is largely insensitive to $\mathrm{SO}_{2}$ or metal concentrations as indicated by sensitivity studies by Alexander et al. (2009). Increases in anthropogenic metal emissions reduce the fraction of sulfate formed by $\mathrm{O}_{3}$ and $\mathrm{H}_{2} \mathrm{O}_{2}$ since the PI. If metal-catalyzed oxidation is not included, the PD-PI difference in $\Delta^{17} \mathrm{O}\left(\mathrm{SO}_{4}^{2-}\right)$ at Alert is overestimated by $0.5 \%$ (Table 2). The decrease in $\mathrm{pH}$ between the $\mathrm{PI}$ and $\mathrm{PD}$ also reduces the fraction of $\mathrm{SO}_{4}^{2-}$ formed by $\mathrm{O}_{3}$ in the aqueous phase. Both increases in anthropogenic metals and a decrease in $\mathrm{pH}$ are needed to explain the observed decrease in $\Delta^{17} \mathrm{O}\left(\mathrm{SO}_{4}^{2-}\right)$.

At WAIS-Divide, the PI period is taken to be $1850 \mathrm{CE}$, as the $\Delta^{17} \mathrm{O}\left(\mathrm{SO}_{4}^{2-}\right)$ measurements prior to 1850 are influenced by the 1810 and Tambora $(1815 \mathrm{CE})$ volcanic erup-
Table 3. The percent (\%) of non-sea salt sulfate formed by each oxidation pathway in the Arctic (Site-A, Greenland and Alert, Canada) and Antarctic (WAIS-Divide). The PI simulation shown here is conducted at a cloud water $\mathrm{pH}$ of 5.0. The PD simulation assumes a cloud water $\mathrm{pH}$ of 4.5 in the Northern Hemisphere and 5.0 in the Southern Hemisphere. The ten-year interannual variability $(1 \sigma)$ is $\leq \pm 3 \%$ in the Arctic and $\leq \pm 2 \%$ in the Antarctic.

\begin{tabular}{lrrrr}
\hline & \multicolumn{2}{c}{ Arctic } & \multicolumn{2}{c}{ Antarctic } \\
& $\mathrm{PI}(\%)$ & $\mathrm{PD}(\%)$ & $\mathrm{PI}(\%)$ & $\mathrm{PD}(\%)$ \\
\hline $\mathrm{SO}_{2}+\mathrm{OH}$ & 17 & 17 & 12 & 11 \\
$\mathrm{~S}(\mathrm{IV})+\mathrm{H}_{2} \mathrm{O}_{2}$ & 61 & 55 & 63 & 67 \\
$\mathrm{~S}(\mathrm{IV})+\mathrm{O}_{3}$ & 13 & 4 & 20 & 17 \\
$\mathrm{~S}(\mathrm{IV})+\mathrm{O}_{2}$ (+metal) & 8 & 21 & 4 & 4 \\
$\mathrm{~S}(\mathrm{IV})+\mathrm{O}_{3}$ (sea salt) & 1 & 2 & 1 & 1 \\
\hline
\end{tabular}

tions and may not represent tropospheric chemistry (Kunasek et al., 2010). We assume that most sulfate deposited at WAIS-Divide, Antarctica originates from oxidation of DMS emitted from the Southern Ocean (Patris et al., 2000). In the southern extratropics, the sulfate production rate peaks between $45^{\circ} \mathrm{S}$ and $75^{\circ} \mathrm{S}$ between the surface and approximately $8.3 \mathrm{~km}$ altitude $(340 \mathrm{hPa})$. Relative modeled PD-PI changes in $\mathrm{O}_{3}, \mathrm{OH}$, and $\mathrm{H}_{2} \mathrm{O}_{2}$ over this region are $+27 \% \pm$ $1 \%,-15.4 \% \pm 0.6 \%$, and $+51 \% \pm 2 \%$, respectively. Despite these oxidant changes, only a very slight change $(-0.2 \%$ o $)$ in the $\Delta^{17} \mathrm{O}\left(\mathrm{SO}_{4}^{2-}\right)$ at WAIS-Divide is modeled, consistent with the observed PD-PI $\Delta^{17} \mathrm{O}\left(\mathrm{SO}_{4}^{2-}\right)$ difference (Table 2). The greater increase in $\mathrm{H}_{2} \mathrm{O}_{2}$ than $\mathrm{O}_{3}$ suppresses $\mathrm{S}$ (IV) $+\mathrm{O}_{3}$ (Fig. 2 and Table 3). Thus, slightly increased oxidation by $\mathrm{H}_{2} \mathrm{O}_{2}$, and decreased oxidation by $\mathrm{OH}$ and $\mathrm{O}_{3}$ results in little net change in $\Delta^{17} \mathrm{O}\left(\mathrm{SO}_{4}^{2-}\right)$ due to offsetting effects of $\Delta^{17} \mathrm{O}(\mathrm{OH})$ and $\Delta^{17} \mathrm{O}\left(\mathrm{O}_{3}\right)$. That is, $\Delta^{17} \mathrm{O}\left(\mathrm{SO}_{4}^{2-}\right)$ at WAISDivide is sensitive to changing oxidant concentrations, but the oxidants change in such a way that there is little net effect on $\Delta^{17} \mathrm{O}\left(\mathrm{SO}_{4}^{2-}\right)$. This conclusion is further corroborated by sensitivity studies using individual PI oxidant fields in otherwise-PD simulations. The difference in $\Delta^{17} \mathrm{O}\left(\mathrm{SO}_{4}^{2-}\right)$ between the PD simulation and the sensitivity studies are $0.2 \%$, $0.03 \%$ o, and $-0.4 \%$ o for PI-O ${ }_{3}, \mathrm{PI}-\mathrm{OH}$, and $\mathrm{PI}-\mathrm{H}_{2} \mathrm{O}_{2}$, respectively. The net effect of these three sensitivity studies is a change in $\Delta^{17} \mathrm{O}\left(\mathrm{SO}_{4}^{2-}\right)$ of $-0.2 \%$, which is consistent with the measured and modeled PD-PI change described above. Although oxidant variability dominates the variability in $\Delta^{17} \mathrm{O}\left(\mathrm{SO}_{4}^{2-}\right)$ at WAIS-Divide, the response of $\Delta^{17} \mathrm{O}\left(\mathrm{SO}_{4}^{2-}\right)$ to PD-PI changes in the oxidant concentrations simulated here is small $(\leq 0.4 \%$ o) .

\subsection{Sensitivity of $\Delta^{17} \mathrm{O}\left(\mathrm{SO}_{4}^{2-}\right)$ to oxidant $\Delta^{17} \mathrm{O}$ assumptions}

Given the uncertainty in the $\Delta^{17} \mathrm{O}$ of oxidants described in Sect. 2, we recalculate the $\Delta^{17} \mathrm{O}\left(\mathrm{SO}_{4}^{2-}\right)$ at both Arctic and 
Antarctic measurement locations using the oxidant $\Delta^{17} \mathrm{O}$ assumptions suggested by Morin et al. (2007) $\left(\Delta^{17} \mathrm{O}\left(\mathrm{O}_{3}\right)=\right.$ $25 \%$ o, $\Delta{ }^{17} \mathrm{O}(\mathrm{OH})=3 \%$ ) . The choice of the $\Delta^{17} \mathrm{O}$ value of the oxidants impacts the absolute value of $\Delta^{17} \mathrm{O}\left(\mathrm{SO}_{4}^{2-}\right)$ by up to $0.5 \%$, but has little impact on the PD-PI change in $\Delta^{17} \mathrm{O}\left(\mathrm{SO}_{4}^{2-}\right)(<0.15 \%)$. Since our analysis focuses on the PD-PI change in $\Delta^{17} \mathrm{O}\left(\mathrm{SO}_{4}^{2-}\right)$ and not the absolute magnitude, the choice of the $\Delta^{17} \mathrm{O}$ values of oxidants has no impact on our conclusions.

\subsection{Sensitivity of $\Delta^{17} \mathrm{O}\left(\mathrm{SO}_{4}^{2-}\right)$ to PI emissions}

Table 2 shows the results from sensitivity studies of PI biomass burning emissions and a low- $\mathrm{O}_{3}$ scenario on $\Delta^{17} \mathrm{O}\left(\mathrm{SO}_{4}^{2-}\right)$. Setting biomass burning emissions to PD levels in the otherwise-PI simulation causes changes relative to the PI base simulation of $+9 \%,-4 \%$, and $+18 \%$ in global tropospheric $\mathrm{O}_{3}, \mathrm{OH}$, and $\mathrm{H}_{2} \mathrm{O}_{2}$, respectively. However, $\Delta^{17} \mathrm{O}\left(\mathrm{SO}_{4}^{2-}\right)$ is not impacted at either WAIS-Divide, Antarctica or Site-A, Greenland, because the oxidant changes associated with biomass burning, particularly changes in $\mathrm{OH}$ and $\mathrm{O}_{3}$, are restricted to low latitudes.

Following Mickley et al. (2001), we reduce $\mathrm{NO}_{\mathrm{x}}$ emissions and double biogenic VOC emissions to try to reproduce late$1800 \mathrm{~s}_{3}$ measurements. This changes global tropospheric $\mathrm{O}_{3}, \mathrm{OH}$, and $\mathrm{H}_{2} \mathrm{O}_{2}$ by $-14 \%,-42 \%$, and $+62 \%$, respectively, relative to the base PI simulation. Surface $\mathrm{O}_{3}$ concentrations at the sites of late-1800 $\mathrm{S}_{3}$ measurements (Marenco et al., 1994; Pavelin et al., 1999; Volz and Kley, 1988) are reduced from the base PI simulation by $5 \mathrm{nmol} \mathrm{mol}^{-1}$, but are still $5 \mathrm{nmol} \mathrm{mol}^{-1}$ higher than both those reported by Mickley et al. (2001) and the measurements. These changes do impact the polar regions, resulting in reductions in the modeled $\Delta^{17} \mathrm{O}\left(\mathrm{SO}_{4}^{2-}\right)$ by $>0.2 \%$ in both regions, relative to the base PI simulation, due to decreases in $\mathrm{O}_{3}$ and increases in $\mathrm{H}_{2} \mathrm{O}_{2}$. The modeled PD-PI difference in $\Delta^{17} \mathrm{O}\left(\mathrm{SO}_{4}^{2-}\right)$ overestimates the PD-PI difference in the WAIS-Divide measurements by $0.4 \%$ (Table 2) and underestimates the PI mean at Site-A by $0.3 \%$, although it does fall within the range of Site-A PI measurements. Thus, the observed and modeled $\Delta^{17} \mathrm{O}\left(\mathrm{SO}_{4}^{2-}\right)$ is inconsistent with lower $\mathrm{PI} \mathrm{O}_{3}$ concentrations from simultaneously decreased $\mathrm{NO}_{\mathrm{x}}$ and increased VOC emissions. However, this does not necessarily mean that ice core $\Delta^{17} \mathrm{O}\left(\mathrm{SO}_{4}^{2-}\right)$ is inconsistent with observations of $\mathrm{PI} \mathrm{O}_{3}$, due to the fact that $\Delta^{17} \mathrm{O}\left(\mathrm{SO}_{4}^{2-}\right)$ is sensitive to the relative, not absolute, concentrations of $\mathrm{O}_{3}, \mathrm{OH}$, and $\mathrm{H}_{2} \mathrm{O}_{2}$. For example, reactive bromine chemistry results in lower PI $\mathrm{O}_{3}$ concentrations, as demonstrated by Parrella et al. (2010). Since halogen chemistry will likely also impact the concentrations of other oxidants, the effects on the $\Delta^{17} \mathrm{O}\left(\mathrm{SO}_{4}^{2-}\right)$, which depends on the relative concentrations of the major $\mathrm{S}(\mathrm{IV})$ oxidants, is presently unknown. In addition, other potential missing reactions in sulfur chemistry provide a source of model uncertainty. For example, if $\mathrm{HSO}_{3}^{-}$oxidation by $\mathrm{HOCl}$ and $\mathrm{HOBr}$ is shown to be as important as suggested by
Vogt et al. (1996) and von Glasow et al. (2002) with the assumed reaction rate constants, the fraction of sulfate formed in the aqueous phase by other pathways will be diminished. This would make $\Delta^{17} \mathrm{O}\left(\mathrm{SO}_{4}^{2-}\right)$ less sensitive to changes in $\mathrm{O}_{3}$ concentrations.

\section{Conclusions}

We modeled present day (PD) and preindustrial (PI) sulfate chemistry, tropospheric oxidant $\left(\mathrm{O}_{3}, \mathrm{OH}, \mathrm{H}_{2} \mathrm{O}_{2}\right)$ concentrations and the resulting oxygen isotopic composition of nonsea salt sulfate $\left(\Delta^{17} \mathrm{O}\left(\mathrm{SO}_{4}^{2-}\right)\right)$ associated with changes in anthropogenic emissions. On large spatial scales, the fraction of sulfate formed by metal-catalyzed oxidation of S(IV) by $\mathrm{O}_{2}$ increases from $11 \%$ in the PI to $22 \%$ in the PD in the Northern Hemisphere, while globally, we find little change in the fraction of sulfate formed in the gas-phase (23\% to $27 \%$ ). PI oxidants are broadly consistent with past modeling studies, and the PD-PI difference in modeled $\Delta^{17} \mathrm{O}\left(\mathrm{SO}_{4}^{2-}\right)$ is consistent with observations from Antarctic and Greenland ice cores and aerosols. At WAIS-Divide, Antarctica, $\Delta^{17} \mathrm{O}\left(\mathrm{SO}_{4}^{2-}\right)$ is sensitive to relative changes in oxidant concentrations, but shows a small response $(\leq 0.4 \%$ ) to modeled PD-PI oxidant changes. Furthermore, the PD-PI changes in oxidants offset each other, yielding no net change in Antarctic $\Delta^{17} \mathrm{O}\left(\mathrm{SO}_{4}^{2-}\right)$. The observations are thus consistent with modeled changes in oxidant concentrations over the Southern Ocean $\left(45^{\circ}-75^{\circ} \mathrm{S}\right)$ of $+27 \%$ in $\mathrm{O}_{3},-15.4 \%$ in $\mathrm{OH}$, and $+51 \%$ in $\mathrm{H}_{2} \mathrm{O}_{2}$ driven by changes in anthropogenic emissions. In the Arctic, $\Delta^{17} \mathrm{O}\left(\mathrm{SO}_{4}^{2-}\right)$ is made insensitive to PD-PI changes in oxidants by the increased importance of oxidation by $\mathrm{O}_{2}$ catalyzed by anthropogenic metals in the $\mathrm{PD}$ and the decreased cloud $\mathrm{pH}$ resulting from anthropogenic emissions of sulfuric and nitric acid precursors. Observed PI $\Delta^{17} \mathrm{O}\left(\mathrm{SO}_{4}^{2-}\right)$ is not consistent with low $\mathrm{PI} \mathrm{O}_{3}$ concentrations caused by imposing low $\mathrm{NO}_{\mathrm{x}}$ and high $\mathrm{VOC}$ emissions in the model. However, since Antarctic $\Delta^{17} \mathrm{O}\left(\mathrm{SO}_{4}^{2-}\right)$ is sensitive to relative changes in oxidants, it is plausible that $\Delta^{17} \mathrm{O}\left(\mathrm{SO}_{4}^{2-}\right)$ could be consistent with observed $\mathrm{PI}_{3}$ concentrations under other oxidant scenarios, such as that modeled by Parrella et al. (2010). This will be a subject of future investigation.

This method for modeling $\Delta^{17} \mathrm{O}\left(\mathrm{SO}_{4}^{2-}\right)$ is now being applied to glacial-interglacial timescales. In contrast to the PD-PI transition, $\Delta^{17} \mathrm{O}\left(\mathrm{SO}_{4}^{2-}\right)$ varies dramatically (by up to $3.5 \%$ ) on the glacial-interglacial timescale in an Antarctic ice core (Alexander et al., 2002).

Acknowledgements. We thank Bob Yantosca for his guidance in preparing the "offline" oxidant fields and acknowledge financial support from grant NSF-AGS 0704169 and a UW Program on Climate Change Graduate Fellowship to E. Sofen.

Edited by: Edited by: J. Kaiser 


\section{References}

Aleksic, N., Roy, K., Sistla, G., Dukett, J., Houck, N., and Casson, P.: Analysis of cloud and precipitation chemistry at Whiteface Mountain, NY, Atmos. Environ., 43, 2709-2716, doi:10.1016/j.atmosenv.2009.02.053, 2009.

Alexander, B., Savarino, J., Barkov, N. I., Delmas, R. J., and Thiemens, M. H.: Climate driven changes in the oxidation pathways of atmospheric sulfur, Geophys. Res. Lett., 29(14), 1685, doi:10.1029/2002GL014879, 2002.

Alexander, B., Thiemens, M. H., Farquhar, J., Kaufman, A. J., Savarino, J., and Delmas, R. J.: East Antarctic ice core sulfur isotope measurements over a complete glacial-interglacial cycle, J. Geophys. Res., 108(D24), 4786, doi:10.1029/2003JD003513, 2003.

Alexander, B., Savarino, J., Kreutz, K. J., and Thiemens, M. H.: Impact of preindustrial biomass-burning emissions on the oxidation pathways of tropospheric sulfur and nitrogen, J. Geophys. Res., 109, D08303, doi:10.1029/2003JD004218, 2004.

Alexander, B., Park, R. J., Jacob, D. J., Li, Q. B., Yantosca, R. M., Savarino, J., Lee, C. C. W., and Thiemens, M. H.: Sulfate formation in sea-salt aerosols: Constraints from oxygen isotopes, J. Geophys. Res., 110, D10307, doi:10.1029/2004JD005659, 2005.

Alexander, B., Park, R. J., Jacob, D. J., and Gong, S.: Transition metal-catalyzed oxidation of atmospheric sulfur: Global implications for the sulfur budget, J. Geophys. Res., 114, D02309, doi:10.1029/2008JD010486, 2009.

Archibald, A. T., Levine, J. G., Abraham, N. L., Cooke, M. C., Edwards, P. M., Heard, D. E., Jenkin, M. E., Karunaharan, A., Pike, R. C., Monks, P. S., Shallcross, D. E., Telford, P. J., Whalley, L. K., and Pyle, J. A.: Impacts of $\mathrm{HO}_{\mathrm{x}}$ regeneration and recycling in the oxidation of isoprene: Consequences for the composition of past, present and future atmospheres, Geophys. Res. Lett., 38, L05804, doi:10.1029/2010GL046520, 2011.

Barkan, E. and Luz, B.: High precision measurements of ${ }^{17} \mathrm{O} /{ }^{16} \mathrm{O}$ and ${ }^{18} \mathrm{O} /{ }^{16} \mathrm{O}$ ratios in $\mathrm{H}_{2} \mathrm{O}$, Rapid Commun. Mass. Sp., 19, 3737-42, doi:10.1002/rcm.2250, 2005.

Barkan, E. and Luz, B.: Diffusivity fractionations of $\mathrm{H}_{2}^{16} \mathrm{O} / \mathrm{H}_{2}^{17} \mathrm{O}$ and $\mathrm{H}_{2}^{16} \mathrm{O} / \mathrm{H}_{2}^{18} \mathrm{O}$ in air and their implications for isotope hydrology, Rapid Commun. Mass. Sp., 21, 2999-3005, doi:10.1002/rcm.3180, 2007.

Bey, I., Jacob, D. J., Yantosca, R. M., Logan, J. A., Field, B. D., Fiore, A. M., Li, Q., Liu, H. Y., Mickley, L. J., and Schultz, M. G.: Global modeling of tropospheric chemistry with assimilated meteorology: Model description and evaluation, J. Geophys. Res., 106(D19), 23073-23095, doi:10.1029/2001JD000807, 2001.

Bhattacharya, S. K., Pandey, A., and Savarino, J.: Determination of intramolecular isotope distribution of ozone by oxidation reaction with silver metal, J. Geophys. Res., 113, D03303, doi:10.1029/2006JD008309, 2008.

Brenninkmeijer, C. A. M., Janssen, C., Kaiser, J., Röckmann, T., Rhee, T. S., and Assonov, S. S.: Isotope effects in the chemistry of atmospheric trace compounds, Chem. Rev., 103, 5125-5162, doi:10.1021/cr020644k, 2003.

Chameides, W. L. and Stelson, A. W.: Aqueous-phase chemical processes in deliquescent sea-salt aerosols: A mechanism that couples the atmospheric cycles of S and sea salt, J. Geophys. Res., 97(D18), 20565-20580, available at: http://www.agu.org/
journals/ABS/1992/92JD01923.shtml, 1992.

Chandra, S., Ziemke, J. R., and Martin, R. V.: Tropospheric ozone at tropical and middle latitudes derived from TOMS/MLS residual: Comparison with a global model, J. Geophys. Res., 108(D9), 4291, doi:10.1029/2002JD002912, 2003.

Chin, M. and Jacob, D. J.: Anthropogenic and natural contributions to tropospheric sulfate: A global model analysis, J. Geophys. Res., 101, D13, 18691-18699, doi:10.1029/96JD01222, 1996.

Cragin, J. H., Giovinetto, M. B., and Gow, A. J.: Baseline acidity of precipitation at the South Pole during the last two millennia, Geophys. Res. Lett., 14(8), 789-792, doi:10.1029/GL014i008p00789, 1987.

Crutzen, P. J. and Zimmermann, P. H.: The changing photochemistry of the troposphere, Tellus A, 43(4), 136-151, doi:10.1034/j.1600-0870.1991.00012.x, 1991.

Dentener, F., Williams, J., and Metzger, S.: Aqueous phase reaction of $\mathrm{HNO}_{4}$ : The impact on tropospheric chemistry, J. Atmos. Chem., 41, 109-134, doi:10.1023/A:1014233910126, 2002.

Dlugokencky, E. J., Lang, P. M., and Masarie, K. A.: Atmospheric methane dry air mole fractions from the NOAA ESRL Carbon Cycle Cooperative Global Air Sampling Network, ftp://ftp.cmdl. noaa.gov/ccg/ch4/flask/event/, 2008.

Dominguez, G., Jackson, T., Brothers, L., Barnett, B., Nguyen, B., and Thiemens, M. H.: Discovery and measurement of an isotopically distinct source of sulfate in Earth's atmosphere, P. Natl. Acad. Sci. USA, 105(35), 12769-12773, doi:10.1073/pnas.0805255105, 2008.

Etheridge, D., Steele, L., Francey, R., and Langenfelds, R.: Ice Core, Firn Air and Archived Air Atmospheric Methane Concentration Data, Tech. rep., NOAA/NGDC Paleoclimatology Program, Boulder CO, USA, 2002.

Feingold, G., Frost, G. J., and Ravishankara, A. R.: Role of $\mathrm{NO}_{3}$ in sulfate production in wintertime northern latitudes, J. Geophys. Res., 107(D22), 4640, doi:10.1029/2002JD002288, 2002.

Fogelman, K. D., Walker, D. M., and Margerum, D. W.: Non-metal redox kinetics - Hypochlorite and hypochlorous acid reactions with sulfite, Inorg. Chem., 28, 986-993, doi:10.1021/ic00305a002, 1989.

Frey, M. M., Bales, R. C., and McConnell, J. R.: Climate sensitivity of the century-scale hydrogen peroxide $\left(\mathrm{H}_{2} \mathrm{O}_{2}\right)$ record preserved in 23 ice cores from West Antarctica, J. Geophys. Res., 111, D21301, doi:10.1029/2005JD006816, 2006.

Giglio, L. and Werf, G. V. D.: Global estimation of burned area using MODIS active fire observations, Atmos. Chem. Phys., 5, 11091-11141, doi:10.5194/acp-6-957-2006, 2006.

Grenfell, J. L., Shindell, D. T., Koch, D., and Rind, D.: Chemistryclimate interactions in the Goddard Institute for Space Studies general circulation model: 2. New insignts into modeling the preindustrial atmosphere, J. Geophys. Res., 106(D24), 3343533451, doi:10.1029/2000JD000090, 2001.

Harder, S., Warren, S. G., and Charlson, R. J.: Sulfate in air and snow at the South Pole: Implications for transport and deposition at sites with low snow accumulation, J. Geophys. Res., 105, GB1011, 22825-22832, doi:10.1029/2000JD900351, 2000.

Hirdman, D., Sodemann, H., Eckhardt, S., Burkhart, J. F., Jefferson, A., Mefford, T., Quinn, P. K., Sharma, S., Ström, J., and Stohl, A.: Source identification of short-lived air pollutants in the Arctic using statistical analysis of measurement data and par- 
ticle dispersion model output, Atmos. Chem. Phys., 10, 669-693, doi:10.5194/acp-10-669-2010, 2010.

Janssen, C.: Intramolecular isotope distribution in heavy ozone $\left({ }^{16} \mathrm{O}^{18} \mathrm{O}^{16} \mathrm{O}\right.$ and $\left.{ }^{16} \mathrm{O}^{16} \mathrm{O}^{18} \mathrm{O}\right)$, J. Geophys. Res., 110, D08308, doi:10.1029/2004JD005479, 2005.

Jenkins, K. A. and Bao, H.: Multiple oxygen and sulfur isotope compositions of atmospheric sulfate in Baton Rouge, LA, USA, Atmos. Environ., 40, 4528-4537, doi:10.1016/j.atmosenv.2006.04.010, 2006.

Johnston, J. C. and Thiemens, M. H.: The isotopic composition of tropospheric ozone in three environments, J. Geophys. Res., 102(D21), 25395-25404, doi:10.1029/97JD02075, 1997.

Kaufman, Y. and Tanre, D.: Effect of variations in super-saturation on the formation of cloud condensation nuclei, Nature, 369, 4548, doi:10.1038/369045a0, 1994.

Krankowsky, D., Bartecki, F., Klees, G. G., Mauersberger, K., and Schellenbach, K.: Measurement of heavy isotope enrichement in tropospheric ozone, Geophys. Res. Lett., 22(13), 1713-1716, doi:10.1029/95GL01436, 1995.

Krankowsky, D., Lammerzahl, P., and Mauersberger, K.: Isotopic measurements of stratospheric ozone, Geophys. Res. Lett., 27(17), 2593-2595, doi:10.1029/2000GL011812, 2000.

Kuhns, H., Green, M., and Etyemezian, V.: Big Bend Regional Aerosol and Visibility Observational (BRAVO) Study Emissions Inventory, Tech. rep., Desert Research Institute, Las Vegas, NV, 2003.

Kunasek, S. A., Alexander, B., Steig, E. J., Sofen, E. D., Jackson, T. L., Thiemens, M. H., McConnell, J. R., Gleason, D. J., and Amos, H. M.: Sulfate sources and oxidation chemistry over the past $\sim 230$ years from sulfur and oxygen isotopes of sulfate in a West Antarctic ice core, J. Geophys. Res., 115, D18313, doi:10.1029/2010JD013846, 2010.

Lamarque, J.-F., Hess, P., Emmons, L., Buja, L., Washington, W., and Granier, C.: Tropospheric ozone evolution between 1890 and 1990, J. Geophys. Res., 110, D08304, doi:10.1029/2004JD005537, 2005.

Lamarque, J.-F., Mcconnell, J. R., Shindell, D. T., Orlando, J. J., and Tyndall, G. S.: Understanding the drivers for the 20th century change of hydrogen peroxide in Antarctic ice-cores, Geophys. Res. Lett., 38, L04810, doi:10.1029/2010GL045992, 2011.

Landais, A., Lathiere, J., Barkan, E., and Luz, B.: Reconsidering the change in global biosphere productivity between the Last Glacial Maximum and present day from the triple oxygen isotopic composition of air trapped in ice cores, Glob. Biogeochem. Cy., 21, 1025, doi:10.1029/2006GB002739, 2007.

Landais, A., Barkan, E., and Luz, B.: Record of $\delta^{18} \mathrm{O}$ and ${ }^{17} \mathrm{O}$-excess in ice from Vostok Antarctica during the last 150,000 years, Geophys. Res. Lett., 35, L02709, doi:10.1029/2007GL032096, 2008.

Langner, J., Rodhe, H., Crutzen, P. J., and Zimmermann, P.: Anthropogenic influence on the distribution of tropospheric sulphate aerosol, Nature, 359, 712-716, doi:10.1038/359712a0, 1992.

Lee, C. C.-W.: Multiple stable oxygen isotopic studies of atmospheric sulfate: A new quantitative way to understand sulfate formation processes in the atmosphere, Ph.D. thesis, University of California, San Diego, La Jolla, California, 2000.

Lee, C. C.-W. and Thiemens, M. H.: The $\delta^{17} \mathrm{O}$ and $\delta^{18} \mathrm{O}$ measurements of atmospheric sulfate from a coastal and high alpine region: A mass-independent isotopic anomaly, J. Geophys. Res.,
106(D15), 17359-17373, doi:10.1029/2000JD900805, 2001.

Lee, C. C. W., Savarino, J., and Thiemens, M. H.: Mass independent oxygen isotopic composition of atmospheric sulfate: Origin and implications for the present and past atmosphere of Earth and Mars, Geophys. Res. Lett., 28(9), 1783-1786, doi:10.1029/2000GL011826, 2001.

Lee, Y. N. and Schwartz, S. E.: Kinetics of oxidation of aqueous sulfur(IV) by nitrogen dioxide, in: Precipitation Scavenging, Dry Deposition and Resuspension, Proceedings of the Fourth International Conference, Santa Monica, California, 29 November3 December 1982, edited by Pruppacher, H., Semonin, R., and Slinn, W. G. N., 453-469, Elsevier, New York, 1983.

Liu, X., Chance, K., Sioris, C. E., Kurosu, T. P., Spurr, R. J. D., Martin, R. V., Fu, T.-M., Logan, J. A., Jacob, D. J., Palmer, P. I., Newchurch, M. J., Megretskaia, I. A., and Chatfield, R. B.: First directly retrieved global distribution of tropospheric column ozone from GOME: Comparison with the GEOS-Chem model, J. Geophys. Res., 111, D02308, doi:10.1029/2005JD006564, 2006.

Lohmann, U. and Feichter, J.: Global indirect aerosol effects: a review, Atmos. Chem. Phys., 5, 715-737, doi:10.5194/acp-5-7152005, 2005.

Luz, B., Barkan, E., Bender, M. L., Thiemens, M. H., and Boering, K. A.: Triple-isotope composition of atmospheric oxygen as a tracer of biosphere productivity, Nature, 400, 547, doi:10.1038/22987, 1999.

Lyons, J. R.: Transfer of mass-independent fractionation in ozone to other oxygen-containing radicals in the atmosphere, Geophys. Res. Lett., 28(17), 3231-3234, doi:10.1029/2000GL012791, 2001.

Marenco, A., Goutget, H., Nédélec, P., and Pagés, J.-P.: Evidence of a long-term increase in tropospheric ozone from Pic du Midi data series: Consequences: Positive radiative forcing, J. Geophys Res., 99(D8), 16617-16632, doi:10.1029/94JD00021, 1994.

Mauersberger, K.: Ozone isotope measurements in the stratosphere, Geophys. Res. Lett., 14(1), 80-83, doi:10.1029/GL014i001p00080, 1987.

Mayewski, P., Lyons, W., Spencer, M., Twickler, M., Dansgaard, W., Koci, B., Davidson, C., and Honrath, R.: Sulfate and nitrate concentrations from a South Greenland ice core, Science, 232, 975-977, doi:10.1126/science.232.4753.975, 1986.

McCabe, J. R., Savarino, J., Alexander, B., Gong, S., and Thiemens, M. H.: Isotopic constraints on non-photochemical sulfate production in the Arctic winter, Geophys. Res. Lett., 33, L05810, doi:10.1029/2005GL025164, 2006.

Michalski, G. and Bhattacharya, S. K.: The role of symmetry in the mass independent isotope effect in ozone, PNAS, 106(14), 5493-5496, doi:10.1073/pnas.0812755106, 2009.

Michalski, G., Scott, Z., Kabiling, M., and Thiemens, M. H.: First measurements and modeling of $\Delta^{17} \mathrm{O}$ in atmospheric nitrate, Geophys. Res. Lett., 30(16), 1870, doi:10.1029/2003GL017015, 2003.

Mickley, L. J., Jacob, D. J., and Rind, D.: Uncertainty in preindustrial abundance of tropospheric ozone: Implications for radiative forcing calculations, J. Geophys. Res., 106(D4), 3389-3399, doi:10.1029/2000JD900594, 2001.

Millet, D. B., Jacob, D. J., Boersma, K. F., Fu, T.-M., Kurosu, T. P., Chance, K., Heald, C. L., and Guenther, A.: Spatial distribution of isoprene emissions from North America derived from formaldehyde column measurements by the OMI satellite sen- 
sor, J. Geophys. Res., 113, D02307, doi:10.1029/2007JD008950, 2008.

Morin, S., Savarino, J., Bekki, S., Gong, S., and Bottenheim, J. W.: Signature of Arctic surface ozone depletion events in the isotope anomaly $\left(\Delta^{17} \mathrm{O}\right)$ of atmospheric nitrate, Atmos. Chem. Phys., 7 , 1451-1469, doi:10.5194/acp-7-1451-2007, 2007.

Morton, J., Barns, J., Schueler, B., and Mauersberger, K.: Laboratory Studies of Heavy Ozone, J. Geophys. Res., 95, 901-907, doi:10.1029/JD095iD01p00901, 1990.

Munger, J. W., Jacob, D. J., Waldman, J. M., and Hoffmann, M. R.: Fogwater chemistry in an urban atmosphere, J. Geophys. Res., 88(C9), 5109-5121, doi:10.1029/JC088iC09p05109, 1983.

Olivier, J. G. J., van Aardenne, J. A., Dentener, F. J., Ganzeveld, L., and Peters, J. A.: Recent trends in global greenhouse gas emissions: regional trends and spatial distribution of key sources, in: Non- $\mathrm{CO}_{2}$ Greenhouse Gases (NCGG-4), edited by: van Amstel, A., 325-30, Millpress, 2005.

Park, R. J., Jacob, D. J., Field, B. D., Yantosca, R. M., and Chin, M.: Natural and transboundary pollution influences on sulfate-nitrate-ammonium aerosols in the United States: Implications for policy, J. Geophys. Res., 109, D15204, doi:10.1029/2003JD004473, 2004.

Parrella, J. P., Evans, M. J., Jacob, D. J., Mickley, L. J., Miller, B., and Liang, Q.: Improved simulation of preindustrial surface ozone in a model with bromine chemistry, AGU Fall Meeting Abstracts, 2010.

Patris, N., Delmas, R. J., and Jouzel, J.: Isotopic signatures of sulfur in shallow Antarctic ice cores, J. Geophys. Res., 105(D6), 70717078, doi:10.1029/1999JD900974, 2000.

Patris, N., Cliff, S. S., Quinn, P. K., Kasem, M., and Thiemens, M. H.: Isotopic analysis of aerosol sulfate and nitrate during ITCT-2k2: Determination of different formation pathways as a function of particle size, J. Geophys. Res., 112, D23301, doi:10.1029/2005JD006214, 2007.

Pavelin, E. G., Johnson, C. E., Rughooputh, S., and Toumi, R.: Evaluation of pre-industrial surface ozone measurements made using Schönbein's method, Atmos. Environ., 33, 919-929, doi:10.1016/S1352-2310(98)00257-X, 1999.

Savarino, J. and Thiemens, M. H.: Analytical procedure to determine both $\delta^{18} \mathrm{O}$ and $\delta^{17} \mathrm{O}$ of $\mathrm{H}_{2} \mathrm{O}_{2}$ in natural water and first measurements, Atmos. Environ., 33, 3683-3690, doi:10.1016/S1352-2310(99)00122-3, 1999.

Savarino, J., Lee, C. C. W., and Thiemens, M. H.: Laboratory oxygen isotopic study of sulfur(IV) oxidation: Origin of the mass-independent oxygen isotopic anomaly in atmospheric sulfates and sulfate mineral deposits on Earth, J. Geophys. Res., 105(D23), 29079-29088, doi:10.1029/2000JD900456, 2000.

Savarino, J., Bhattacharya, S. K., Morin, S., Baroni, M., and Doussin, J.-F.: The $\mathrm{NO}+\mathrm{O}_{3}$ reaction: A triple oxygen isotope perspective on the reaction dynamics and atmospheric implications for the transfer of the ozone isotope anomaly, J. Chem. Phys., 128, 194303, doi:10.1063/1.2917581, 2008.

Sigg, A. and Neftel, A.: Evidence for a $50 \%$ increase in $\mathrm{H}_{2} \mathrm{O}_{2}$ over the past 200 years from a Greenland ice core, Nature, 351, 557559, doi:10.1038/351557a0, 1991.

Smith, S. J., van Aardenne, J., Klimont, Z., Andres, R. J., Volke, A., and Delgado Arias, S.: Anthropogenic sulfur dioxide emissions: 1850-2005, Atmos. Chem. Phys., 11, 1101-1116, doi:10.5194/acp-11-1101-2011, 2011.
Solomon, S., Qin, D., Manning, M., Chen, Z., Marquis, M., Averyt, K. B., Tignor, M., and Miller, H. L., (Eds.): Climate Change 2007 - The Physical Science Basis: Working Group I Contribution to the Fourth Assessment Report of the IPCC, Cambridge University Press, Cambridge, UK and New York, NY, USA, 2007.

Staffelbach, T., Neftel, A., Stauffer, B., and Jacob, D.: A record of the atmospheric methane sink from formaldehyde in polar ice cores, Nature, 349, 603-605, doi:10.1038/349603a0, 1991.

Stone, D., Evans, M. J., Edwards, P. M., Commane, R., Ingham, T., Rickard, A. R., Brookes, D. M., Hopkins, J., Leigh, R. J., Lewis, A. C., Monks, P. S., Oram, D., Reeves, C. E., Stewart, D., and Heard, D. E.: Isoprene oxidation mechanisms: measurements and modelling of $\mathrm{OH}$ and $\mathrm{HO}_{2}$ over a South-East Asian tropical rainforest during the OP3 field campaign, Atmos. Chem. Phys. Discuss., 11, 10343-10401, doi:10.5194/acpd-11-103432011, 2011.

Straub, D. J., Lee, T., and Collett, J. L.: Chemical composition of marine stratocumulus clouds over the eastern Pacific Ocean, J. Geophys. Res., 112, D04307, doi:10.1029/2006JD007439, 2007.

Streets, D. G., Zhang, Q., Wang, L., He, K., Hao, J., Wu, Y., Tang, Y., and Carmichael, G. R.: Revisiting China's CO emissions after the Transport and Chemical Evolution over the Pacific (TRACE-P) mission: Synthesis of inventories, atmospheric modeling, and observations, J. Geophys. Res., 111, D14306, doi:10.1029/2006JD007118, 2006.

Thiemens, M. H.: History and Applications of MassIndependent Isotope Effectsa, Ann. Rev. Earth Pl. Sc., 34, 217, doi:10.1146/annurev.earth.34.031405.125026, 2006.

Thiemens, M. H. and Heidenreich, J.: The mass-independent fractionation of oxygen: A novel isotope effect and its possible cosmochemical implications, Science, 219, 1073-1075, doi:10.1126/science.219.4588.1073, 1983.

Thompson, A. M.: The oxidizing capacity of the Earth's atmosphere: Probable past and future changes., Science, 256, 11571165, doi:10.1126/science.256.5060.1157, 1992.

Thompson, A. M., Chappellaz, J. A., Fung, I. Y., and Kucsera, T. L.: The atmospheric $\mathrm{CH}_{4}$ increase since the Last Glacial Maximum. II - Interactions with oxidants, Tellus, 45, 242-257, doi:10.1034/j.1600-0889.1993.t01-2-00003.x, 1993.

Troy, R. C. and Margerum, D. W.: Non-metal redox kinetics: Hypobromite and hypobromous acid reactions with iodide and with sulfite and the hydrolysis of bromosulfate, Inorg. Chem., 30, 3538-3543, doi:10.1021/ic00018a028, 1991.

Usher, C. R., Michel, A. E., and Grassian, V. H.: Reactions on mineral dust, Chem. Rev., 103, 4883-4940, doi:10.1021/cr020657y, 2003.

Vestreng, V. and Klein, H.: Emission data reported to UNECE/EMEP: Quality insurance and trend analysis \& Presentation of WebDab, MSC-W Status Report, Tech. rep., Norwegian MEteorological Institute, Oslo, Norway, http://www.emep.int/publ/ reports/2002/mscw_note_1_2002.pdf, 2002.

Vogt, R., Crutzen, P. J., and Sander, R.: A mechanism for halogen release from sea-salt aerosol in the remote marine boundary layer, Nature, 383, 327-330, doi:10.1038/383327a0, 1996.

Volz, A. and Kley, D.: Evauluation of the Montsouris seris of ozone measurements made in the nineteenth century, Nature, 332, 240242, doi:10.1038/332240a0, 1988.

von Glasow, R., Sander, R., Bott, A., and Crutzen, P. J.: Model- 
ing halogen chemistry in the marine boundary layer 2 . Interactions with sulfur and the cloud-covered MBL, J. Geophys. Res., 107(D17), 4323, doi:10.1029/2001JD000943, 2002.

Wang, M., Ghan, S., Ovchinnikov, M., Liu, X., Easter, R., Kassianov, E., Qian, Y., and Morrison, H.: Aerosol indirect effects in a multi-scale aerosol-climate model PNNL-MMF, Atmos. Chem. Phys. Discuss., 11, 3399-3459, doi:10.5194/acpd11-3399-2011, 2011.

Wang, Y. and Jacob, D. J.: Anthropogenic forcing on tropospheric ozone and $\mathrm{OH}$ since preindustrial times, J. Geophys. Res., 103(D23), 31123-31135, doi:10.1029/1998JD100004, 1998.

Wang, Y., Jacob, D. J., and Logan, J. A.: Global simulation of tropospheric $\mathrm{O}_{3}-\mathrm{NO}_{\mathrm{x}}$-hydrocarbon chemistry 1 . Model formulation, J. Geophys. Res., 103(D9), 10713-10725, doi:10.1029/98JD00158, 1998.
Wang, Z., Chappellaz, J., Park, K., and Mak, J. E.: Large variations in Southern Hemisphere biomass burning during the last 650 years, Science, 330, 1663-1666, doi:10.1126/science.1197257, 2010.

Warneck, P.: The relative importance of various pathways for the oxidation of sulfur dioxide and nitrogen dioxide in sunlit continental fair weather clouds, Phys. Chem. Chem. Phys., 1, 54715483, doi:10.1039/A906558J, 1999.

Wu, S., Mickley, L. J., Jacob, D. J., Logan, J. A., Yantosca, R. M., and Rind, D.: Why are there large differences between models in global budgets of tropospheric ozone?, J. Geophys. Res., 112, D05302, doi:10.1029/2006JD007801, 2007. 